\title{
Biotic community and landscape changes around the Eocene-Oligocene transition at Shapaja, Peruvian Amazonia: regional or global drivers?
}

Pierre-Olivier Antoine ${ }^{* 1}$, Johan Yans ${ }^{2}$, Angélica Aliaga Castillo ${ }^{3,4}$, Narla Stutz $^{1,5}$, M. Alejandra Abello ${ }^{6,7}$, Sylvain Adnet ${ }^{1}$, Michele Andriolli Custódio ${ }^{8,9}$, Aldo Benites-Palomino ${ }^{3,10}$, Guillaume Billet $^{11}$, Myriam Boivin ${ }^{12}$, Fabiany Herrera ${ }^{13}$, Carlos Jaramillo ${ }^{1,4,14}$, Camila Mártinez ${ }^{4,15}$, Federico Moreno $^{4,16}$, Rosa E. Navarrete ${ }^{17}$, Francisco Ricardo Negri ${ }^{18}$, Francisco Parra ${ }^{17,19}$, François Pujos ${ }^{7,20}$, Jean-Claude Rage $t^{11}$, Ana Maria Ribeiro ${ }^{5,21}$, Céline Robinet ${ }^{6}$, Martin Roddaz ${ }^{8,9}$, Julia V. TejadaLara $^{1,3}$, Rafael Varas-Malca ${ }^{3,22}$, Roberto Ventura Santos ${ }^{8}$, Rodolfo Salas-Gismondi ${ }^{3,22}$, and Laurent Marivaux $^{1}$

${ }^{1}$ Institut des Sciences de l'Evolution de Montpellier, Univ Montpellier, CNRS, IRD, EPHE, Montpellier, France

${ }^{2}$ University of Namur, Department of Geology, Institute of Life, Earth and Environment, ILEE, 61 rue de Bruxelles, 5000 Namur, Belgium

${ }^{3}$ Departamento de Paleontología de Vertebrados, Museo de Historia Natural - Universidad Nacional Mayor de San Marcos, Lima, Peru

${ }^{4}$ Smithsonian Tropical Research Institute, Unit 0948, APO AA 34002, Balboa, Ancon, 0843-03092, Panama

${ }^{5}$ Programa de Pós-Graduação em Geociências, Universidade Federal do Rio Grande do Sul, Av. Bento Gonçalves, 9500, 91501-970 Porto Alegre, Brazil

${ }^{6}$ Unidades de investigación Anexo Museo, Facultad de Ciencias Naturales y Museo (UNLP). Av. 60 y 122. B1900FWA, La Plata, Argentina

${ }^{7}$ Consejo Nacional de Investigaciones Científicas y Técnicas (CONICET), Argentina

${ }^{8}$ Laboratório de Geocronologia, Instituto de Geociências, Universidade de Brasília, Brasília, DF 70910-000, Brazil

${ }^{9}$ Géosciences-Environnement Toulouse, Université de Toulouse; UPS (SVT-OMP); CNRS; IRD; 14 Avenue Édouard Belin, F-31400 Toulouse, France

${ }^{10}$ Paläontologisches Institut und Museum, Universität Zürich, Karl-Schmid-Straße 4, Zürich, 8006, Switzerland

${ }^{11}$ Sorbonne Universités, CR2P, MNHN, CNRS, UPMC-Paris 6, Muséum national d'Histoire naturelle, CP 38, 8 rue Buffon, 75231 Paris cedex 05, France

${ }^{12}$ Instituto de Ecorregiones Andinas (INECOA), Universidad Nacional de Jujuy, CONICET, IdGyM, Av. Bolivia 1661, San Salvador de Jujuy 4600, Jujuy, Argentina

${ }^{13}$ Chicago Botanic Garden, 1000 Lake Cook Rd, Glencoe, IL 60022, USA

${ }^{14}$ Department of Geology, Faculty of Sciences, University of Salamanca, Salamanca, Spain

${ }^{15}$ Departamento de Ciencias Biológicas, Facultad de Ciencias, Universidad EAFIT, Medellín, Colombia

${ }^{16}$ Earth \& Environmental Sciences, University of Rochester, 227 Hutchison Hall, University of Rochester, Rochester, NY, 14627, USA.

${ }^{17}$ Paleosedes E.U. Tv 27 n57-49 Campin, Bogotá, Colombia

${ }^{18}$ Laboratório de Paleontologia, Universidade Federal do Acre, Cruzeiro do Sul, Brésil

${ }^{19}$ Laboratorio de Bioquimio-Estratigrafía, Facultad de Geociencias, Universidad Nacional de Colombia, Bogotá, Colombia

${ }^{20}$ Instituto Argentino de Nivología, Glaciología y Ciencias Ambientales (IANIGLA), CCT-CONICET-Mendoza, Av. Ruiz Leal s/n, Parque Gral. San Martín, 5500 Mendoza, Argentina

${ }^{21}$ Museu de Ciências Naturais, Secretaria do Meio Ambiente e Infraestrutura do Rio Grande do Sul, Av. Salvador França, 1427, 90690-000, Porto Algre, Brazil.

${ }^{22}$ BioGeoCiencias Lab, Facultad de Ciencias y Filosofía/CIDIS, Universidad Peruana Cayetano Heredia, Lima, Perú

*Corresponding author: pierre-olivier.antoine@umontpellier.fr 
Keywords. Andes-Amazonia transition; Pozo System demise; paleontology; sedimentary geology; chemostratigraphy; paleoenvironments.

\section{Abstract}

Since 2012, we have investigated a stratigraphic section encompassing the late Eocene-earliest Oligocene interval at Shapaja (Tarapoto area, Peruvian Amazonia, $c a .7^{\circ} \mathrm{S}$ ), through paleontological and geological fieldwork. The measured sedimentary series (120 m-thick [West] plus $90 \mathrm{~m}$-thick [East]), assigned to the upper member of the Pozo Formation, records fluvial micro-conglomeratic lenses intercalated with floodplain and evaporite-rich fine red deposits, estuarine/coastal-plain tidally-influenced fine sandstones, and oxbow lake nodule-rich blue clays. This sedimentary shift coincides locally with the demise of the large Eocene coastal-plain wetland known as Pozo System. The late Eocene-early Oligocene Shapaja section was extensively sampled for chemostratigraphy $\left(\delta^{13} \mathrm{C}\right.$ on dispersed organic matter and pedogenic carbonate nodules), which in turn allowed for refining the location of the Eocene-Oligocene Transition (EOT) and other climatic events recognized at a global scale (i.e., Oi-1 and $\mathrm{Oi}-1 \mathrm{1a}$ ). The section has yielded nine fossil localities with plant remains (leaves, wood, charophytes, and palynomorphs), mollusks, decapods, and/or vertebrates (selachians, actinopterygians, lungfishes, amphibians, sauropsids, and mammals), documenting $\sim 130$ distinct taxa. Four localities of the upper member of the Pozo Formation at Shapaja predate the EOT, one is clearly within the EOT, while four are earliest/early Oligocene in age. The small leaf impressions found along the Shapaja section could be indicative of dry and/or seasonal conditions for this region throughout and after the EOT. Monkeys, indicative of tropical rainforest environments, are only recorded in a latest Eocene locality (TAR-21). Two biotic turnovers are perceptible in the selachian, metatherian, and rodent communities, well before the EOT [ 35-36 Ma] and a few hundred thousand years after the EOT [ 33 Ma]. The latter turnover seems to be primarily related to a global sea-level drop (ichthyofauna: marine-littoral elements replaced by obligate freshwater taxa) and/or the onset of a drier and more seasonal climate in early Oligocene times (terrestrial components). Changes in the structure of the Shapaja paleocommunities were mostly locally driven by the flexural subsidence during the late Eocene, and then globally driven by the earliest Oligocene climatic deterioration.

\section{Introduction}

The Eocene-Oligocene transition (EOT, ca. 33.9 million years ago) was one of the most dramatic episodes of climatic, environmental, and biotic change recorded throughout the Cenozoic era. It corresponds to a phase of oceanic reorganization, global cooling $\left(c a .4^{\circ} \mathrm{C}\right)$, and to onset of semi-permanent ice sheets on Antarctica, which led to a noticeable drop in global sea level (Mudelsee et al., 2014; Miller et al., 2020). Basically, the EOT marks the rapid shift from the Paleocene-Eocene "greenhouse" Earth to the "icehouse" Earth during the earliest Oligocene. The prevailing proposed mechanisms of that climatic deterioration include a decrease in the concentration of atmospheric $\mathrm{CO}_{2}$ (e.g., Zachos et al., 2001, 2008; DeConto \& Pollard, 2003; Pagani et al., 2005; Westerhold et al., 2020) and the opening of Southern Ocean gateways (Tasmania Sea and Drake Passage) that established the Antarctic circumpolar current (e.g., Toumoulin et al., 2020). Important changes occurred in floras and faunas around the world, reflecting the shift from warm to colder/drier climatic regimes (e.g., Miller et al., 1991, Coxall and Pearson, 2007; DupontNivet et al., 2007; Hutchinson et al., 2018). This climatic transition consisted of alternating phases of expansion and contraction of Antarctic ice sheets, reflected in successive episodes of sea level rise and fall (Miller et al., 2020). Accordingly, the EOT was an interval of substantial ecological reorganization, biotic turnovers, dispersals, extinction, provincialism, and speciation in many 
biological groups, with patterns varying from landmass to landmass and across latitudes (e.g., 103 Stehlin, 1909; Savage \& Russell, 1983; Janis, 1993; Meng \& McKenna, 1998; Marivaux et al., 2005, 104 2017a,b; Coxall \& Pearson, 2007; Seiffert, 2007; Liu et al., 2009; Goin et al., 2010; Beard et al., 105 2017; Godfrey et al., 2020).

Continental proxies crossing the EOT, however, are somewhat sparse and they seem to be much blurrier than in the marine records (e.g., Berggren \& Prothero, 1992; Coxall \& Pearson, 2007; Zachos et al., 2008; Tramoy et al., 2016; Pound \& Salzmann; 2017; Westerhold et al., 2020). Furthermore, continental fossil records often lack the accurate time resolution that allows for a precise correlation of biotic events and pulses with the earliest Oligocene glacial maxima, as recorded by marine records. Also, compared with northern continents (e.g., Coxall \& Pearson, 2007; Zanazzi et al., 2007), much less is known about the tempo and intensity of biotic and environmental changes that occurred across the EOT in tropical-equatorial areas of Africa (e.g., Seiffert, 2007; Beard et al., 2017; Marivaux et al., 2017a,b; Benammi et al., 2019), South Asia (Marivaux et al., 2002, 2005; Ni et al., 2016), and more markedly, of South America (Jaramillo et al., 2006; Hoorn et al., 2010). Surprisingly, although with regionally-heterogeneous floras, no drastic change in paleo-biome distribution, terrestrial isotopes and phytolith assemblages has been detected between the late Eocene and the early Oligocene in the Southern cone of South America (e.g., Dunn et al., 2015; Kohn et al., 2015; Pound \& Salzmann, 2017; Barreda \& Palazzesi, in revision, this issue). In contrast, substantial changes are recorded on palynomorphs at lower latitudes, especially from north-east South America (Colombia and Venezuela), with a rapid phase around the EOT, likely linked to the onset of the Antarctic glaciation (Jaramillo et al., 2006). At tropical-equatorial latitudes, it seems that the global cooling provoked both a sustained drop in precipitation and increased seasonality. So far, based only on vegetation proxies, the aridification resulted in a decrease of plant morpho-diversity and in the opening of terrestrial environments, 


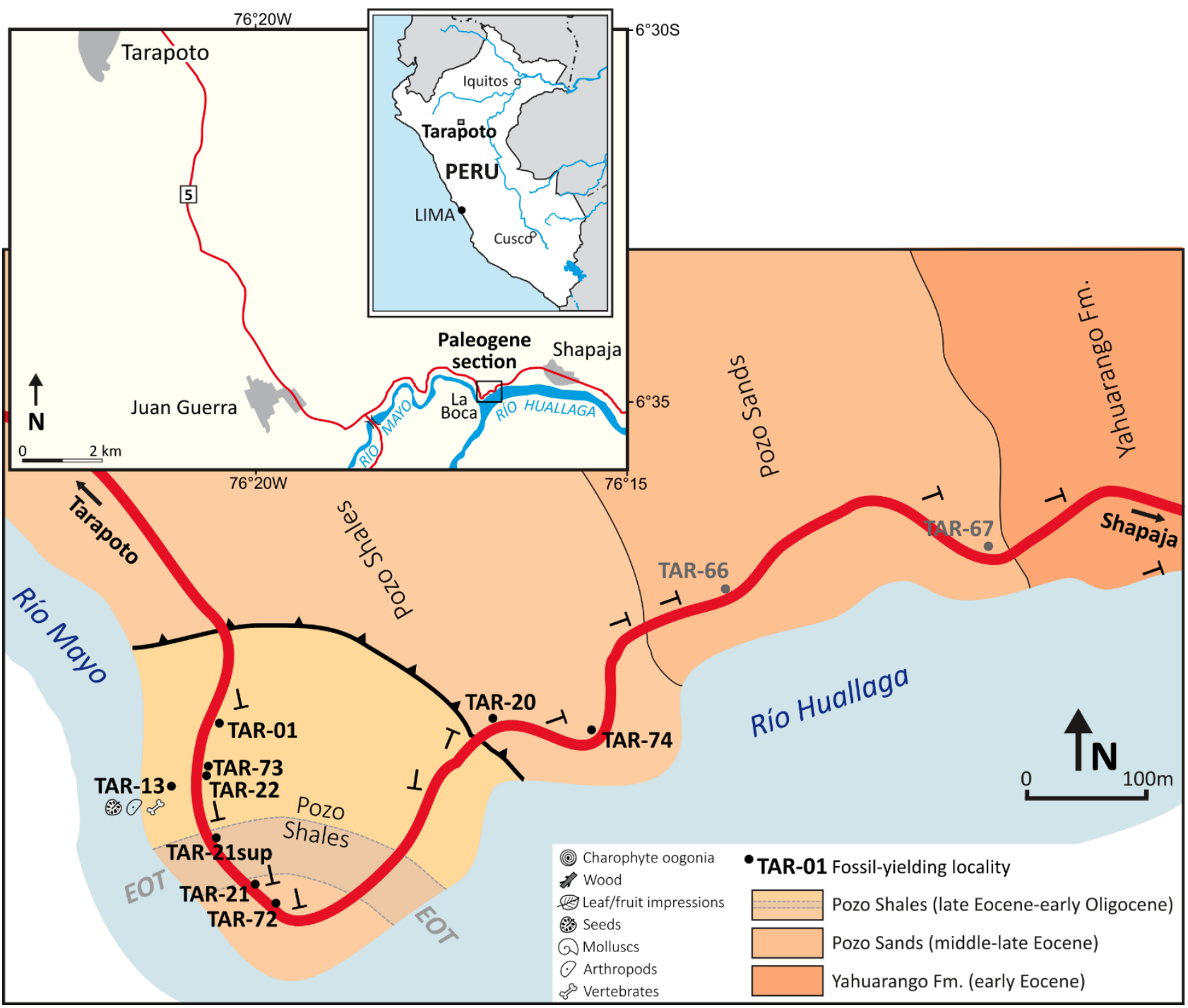

Fig. 1. Location (A) and geological map (B) of the studied area, around the Río Huallaga-Río Mayo confluence, with fossil localities of interest, at Shapaja, San Martín Department, Peruvian Amazonia. TAR-67 and TAR-66 localities (Pozo Sands; late middle-early late Eocene), significantly older than all other TAR- localities (based on stratigraphy, lithology, and distinct mammalian faunas). EOT, Eocene-Oligocene transition. Ideograms denote fossil content for the locality TAR13 , which is situated outside the measured sections illustrated in Figure 2.

Here, we describe nine plurispecific fossil localities originating from Shapaja, San Martín Department, at $c a .7^{\circ} \mathrm{S}$ in Peruvian Amazonia, and distributed along a $120+50 \mathrm{~m}$-thick section (Figs. 1, 2; see Geological setting for more details). This stratigraphic interval belongs to the upper member of the Pozo Formation [Fm.] (Pozo Shales) and encompasses the late Eocene-earliest Oligocene interval (Fig. 2). The concerned fossil localities yielded plant remains (leaves, seeds, wood, charophytes, and palynomorphs), mollusks, decapods, and/or vertebrates (selachians, actinopterygians, lungfishes, amphibians, turtles, crocodylomorphs, and mammals. Decapods and rodents originating from some of the concerned localities (TAR-20, TAR-21, TAR-22, TAR-13, and TAR-01) were previously studied by Klaus et al. (2017) and Boivin et al. (2018, 2019a, 2019b), respectively.

In the absence of radioisotopic datings so far available in the Shapaja section (e.g., through $\mathrm{Ar} / \mathrm{Ar}$ ages on volcaniclastic sediments or $\mathrm{U} / \mathrm{Pb}$ ages on detrital zircons), this section was extensively sampled for chemostratigraphy $\left(\delta^{13} \mathrm{C}\right.$ on dispersed organic matter and pedogenic carbonate nodules) in order to refine the local stratigraphy and to accurately locate the EOT, as 
well as hypothetic hints of early Oligocene glaciations (Fig. 2; Zachos et al., 2001, 2008; Vandenberghe et al., 2012; Westerhold et al., 2020). Indeed, C-isotopes on both organic matter and pedogenic nodules have been judged as reliable material for chemostratigraphy in many sections and paleoenvironments over the world, including terrestrial settings (e.g., Gröcke et al., 1999; Magioncalda et al., 2004; Noiret et al., 2016 and references therein). Ultimately, we also aim to test the occurrence of biotic turnovers related to the EOT and subsequent climatic events, through the analysis of potential shifts in terrestrial and aquatic communities along the concerned section.

\section{Regional setting}

Thick Cretaceous-Cenozoic sections crop out continuously along river banks and newly-cut roads in the San Martín Department. Hermoza et al. (2005) and Roddaz et al. (2010) provided a synthetic overview of Cenozoic tectono-sedimentary history of Northern Peruvian foreland basin, recently refined by Eude et al. (2015) and Moreno et al. (2020). The studied section, overhanging the confluence between the Ríos Mayo and Huallaga (Fig. 1), was considered as documenting the sandstone-dominated Chambira Fm., i.e. allegedly late Oligocene-early Miocene in age, in the Utcurarca geological map, without any chronostratigraphic or biostratigraphic constraints (Sánchez Fernández et al., 1997). Nevertheless, given that floodplain and fine-grained detrital deposits (shales) are fully dominating, the concerned sequence might be referable as a whole to the upper member of the underlying Pozo Fm. instead ("Upper Pozo (shale) member"; see Hermoza et al., 2005; Roddaz et al., 2010). This shale-dominated member, further characterized by shallow marine/littoral components, most probably spans the late Eocene-late Oligocene interval in the northern Peruvian foreland basin (Roddaz et al., 2010; Antoine et al., 2016). Similar deposits assigned to the Upper Pozo Shale member recently yielded various fossil remains near Juanjuí, 80 km further to the SW (TAR-47, TAR-49, and TAR-50 localities; Assemat et al., 2019). In contrast, the base of the Chambira Fm. (late Oligocene) overlies unconformably the sanddominated lower member of the Pozo Fm. (Pozo Sands, late middle-late Eocene) in the Ucayali Basin, near Contamana (Antoine et al., 2016).

The fossil-yielding stratigraphic subsections at Shapaja are i) $120 \mathrm{~m}$-thick, with a general N80-110 direction and $20-30^{\circ} \mathrm{W}$ dipping for the western part and ii) $90 \mathrm{~m}$-thick, with a general $\mathrm{N} 160$ direction and $45^{\circ} \mathrm{W}$ dipping for the eastern part. A reverse fault delimits both sections, with the eastern section overriding the western one (Fig. 1). A $\sim 10 \mathrm{~m}$-thick overlap is hypothesized between the eastern and the western sections, on lithostratigraphical grounds. On both sides, the stratigraphic sequence is dominated by fine-grained sediments (red shales and siltites), with gypsum veins distributed obliquely with respect to the general dipping, and alternating with fineto coarse-grained yellow sandstones, with oxidized leaf litters (TAR-74, TAR-20, TAR-21sup, and TAR-22 localities) and clay pebble-rich grey microconglomerates (TAR-72, TAR-21, and TAR-73 localities). Two lenses of carbonate nodule-rich blue clays further occur in the upper part of the western section (TAR-13 and TAR-01 localities). Given the general geometry of deposits and thrust, all nine successive fossil localities are distributed within these coarse-grained bodies, with the following fossil locality sequence: TAR-74, TAR-20, TAR-72, TAR-21, TAR-21sup, TAR-13, TAR22, TAR-73, and TAR-01 (Fig. 1C). Lower in the eastern series two more fossil-yielding localities were found, TAR-67 and TAR-66. These two localities are assignable to the lower member of the Pozo Fm. (Pozo Sands) and they document a noticeably-earlier stratigraphic interval (late middleearly late Eocene; Fig. 1). Their detailed analysis falls beyond the scope of the current work. 
The fossil localities studied here were discovered in 2012-2018 and investigated in 2012-2019 (see SI). Samplings for chemostratigraphical analyses were performed in 2018.

\subsection{Chemostratigraphy}

A total of 168 samples were collected in both western and eastern sections at Shapaja (137 and 31 samples, respectively). Carbon isotope analyses on dispersed organic matter $\left(\delta^{13} \mathrm{C}_{\text {org }}\right)$ were performed on 121 samples (Table 1). Samples not considered for organics had too low carbon content and/or major traces of roots, deep oxidation/weathering, preventing robust isotopic analyses. Carbon isotope analyses on pedogenic nodules $\left(\delta^{13} C_{\text {nod }}\right)$ were performed on 92 samples, typically in red/brown pedogenic marls and siltstones (Table 1 ). In the Shapaja section, C-isotope analyses on bulk (carbonates) were not performed due to the fact that secondary fluids most likely perturbed the primary signal.

Organic matter of the sediments was isolated, following the procedure described in Yans et al. (2010) refined by Storme et al. (2012). The dispersed organic carbon isotope analyses $\left(\delta^{13} \mathrm{C}_{\text {org }}\right)$ are based on powdered rock samples of about 3 to $10 \mathrm{~g}$, acidified in $25 \% \mathrm{HCl}$ solution during 2 hours in order to remove carbonate. Soluble salts were removed by repetitive (1-6) centrifuging $(4,000$ revolutions per minute) with deionized water until a neutral sediment was obtained. Finally, residues were dried at $35^{\circ} \mathrm{C}$ and powdered again. Analyses were performed with an elemental analyzer (Carlo-Erba 1110) connected online to a ThermoFinnigan Delta V Plus mass spectrometer at the University of Erlangen. Accuracy and reproducibility of the analyses were checked by replicate analyses of international standards USGS40 and USGS41. The reproducibility of analyses is within $0.2 \%$ o $(1 \sigma)$.

Pedogenic nodules $\left(\delta^{13} \mathrm{C}_{\text {nod }}\right)$ were crushed and powders reacted with $100 \%$ phosphoric acid at $70^{\circ}$ C using a Gasbench II connected to a ThermoFinnigan V Plus ${ }^{\circledR}$ masspectrometer at the University of Erlangen. Isotopic compositions are calibrated with standards NBS19 for $\delta^{13} C_{\text {nod. }}$. Reproducibilities are within +/- $0.05 \%$ o $(1 \sigma)$. Each sample was analyzed 1 to 3 times. Organic ${ }^{13} \mathrm{C} /{ }^{12} \mathrm{C}$ values are normalized to the international VPDB standard (Vienna Pee Dee Belemnite). Total organic content (\%TOC) was measured with an elemental analyzer LECO ${ }^{\circledR}$ (CS-200). The $\mathrm{CaCO}_{3}(\%)$ content of the samples was measured with a Bernard Calcimeter.

\subsection{Fossil plants}

The macrofossil plant material of the Shapaja section corresponds to impressions of non-monocot angiosperm leaves and fruits, which were studied and stored at the Paleontological Collection of the Museo de Historia Natural de la Universidad Nacional Mayor de San Marcos Lima, Peru (DPVMHN-UNMSM; inventory numbers PVMUSM-60 to -83). Fossil leaves were organized and described by morphotypes following the method proposed by Peppe et al. (2008). Each morphotype has a two-letter prefix (PZ) based on the formation name (Pozo Formation) plus a number starting from one.

Fossil seeds were recovered by screenwashing (seed additional details below) from samples TAR74, TAR-20, TAR-21, TAR-13, TAR-22, TAR-73, and TAR-01. The specimens are mostly preserved as silicified and/or iron-rich locule casts, and less commonly as carbonized remains.

Taxonomic affinities of the leaf, fruit, and seed morphotypes were proposed when possible based on the presence of taxonomically-informative characters (shape, size, margin type or venation patterns in leaves), extant material available for comparison, and the level of completeness of the description of each morphotype.

\subsection{Other fossil remains (charophytes, mollusks, decapods, and vertebrates)}


Large mollusk and vertebrate specimens uncovered were prepared mechanically in the field and at lab. Small vertebrate specimens, decapod claws, and micromollusks were concentrated by screenwashing ca. 2,000 kg of raw sediment, with $2 \mathrm{~mm}, 1 \mathrm{~mm}$, and $0.7 \mathrm{~mm}$ meshes (12-762 kg per locality; see SI for more details), using highly-diluted hydrogen peroxide, in 2012-2019. This protocol also allowed for obtaining charophyte oogonia and seeds, as well as carbonized and silicified wood chunks. Except when mentioned, all concerned specimens are permanently housed in the DPV-MHN-UNMSM.

The palynological preparation was carried out at the Stratigraphy Research Institute (IIES) at the Universidad de Caldas, Manizales, Colombia, following the Traverse's (2007) standard procedure (37\% hydrochloric acid, Hydrofluoric acid at $70 \%$ and density separation using Zinc Chloride). Samples were mounted using Canada balsam.

\section{Results}

\subsection{Chemostratigraphy}

Carbon isotopic values on dispersed organic matter $\left(\delta^{13} \mathrm{C}_{\text {org }}\right)$ range from -26.9 to $-21.0 \%$ o (Table 1 ). These data are in good agreement with the expected $\delta^{13} \mathrm{C}$ values on organics at the EoceneOligocene interval (see Sarkar et al., 2003; Benammi et al., 2019). Carbon isotopic values on pedogenic nodules $\left(\delta^{13} C_{\text {nod }}\right)$ range from $-5.7 \%$ to $-11.8 \%$ (Table 1 ).

We provide a detailed description of all the isotopic results in SI. The most relevant chemostratigraphic features are as follows: in the Eastern section, C-isotope values on both organics and pedogenic nodules show (from base to top) a short positive trend followed by a quite long negative trend (Fig. 2; Table 1). In the Western section, two main positive excursions are observed. This pattern is particularly obvious for C-isotope data on pedogenic nodules (Fig. 2; Table 1).

TOC content is very low for all the samples (around $0.05 \%$ ), whereas the $\mathrm{CaCO} 3$ contents much more satisfactorily range from $5 \%$ to $66 \%$ depending on the samples (Table 1 ). 


\begin{tabular}{|c|c|c|c|c|c|}
\hline Section & Sample & $\begin{array}{c}\text { Height } \\
(\mathrm{m})\end{array}$ & $\begin{array}{c}\mathrm{CaCO}_{3} \\
(\%)\end{array}$ & $\begin{array}{c}\delta^{13} C_{\text {org }}(\%) \text { - } \\
\text { organics }\end{array}$ & $\begin{array}{c}\delta^{13} C_{\text {nod }}(\%) \\
\text { nodules }\end{array}$ \\
\hline Western & 18TP99 & 115.5 & 11 & -24.5 & -11 \\
\hline Western & 18TP98 & 113.5 & 8 & -26.5 & -6.9 \\
\hline Western & 18TP97 & 112 & 6 & TOC too low & - \\
\hline Western & 18TP96 & 110.5 & 13 & TOC too low & -9.8 \\
\hline Western & 18TP95 & 109 & 16 & TOC too low & -10.7 \\
\hline Western & 18TP94 & 108 & 18 & -23.9 & -9.2 \\
\hline Western & 18TP93 & 107.9 & 49 & TOC too low & - \\
\hline Western & 18TP92 & 107.5 & 17 & -24.5 & -11.5 \\
\hline Western & 18TP91 & 106.4 & 16 & TOC too low & - \\
\hline Western & 18TP90 & 106 & 8 & -25.4 & -9.5 \\
\hline Western & 18TP89 & 105.6 & 8 & -25 & -9.2 \\
\hline Western & 18TP88 & 105.1 & 8 & -25.7 & -10 \\
\hline Western & $18 T P 87$ & 104 & 13 & -25.5 & -11.2 \\
\hline Western & 18TP86 & 102.8 & 16 & -26.1 & -10 \\
\hline Western & 18TP85 & 101.1 & 17 & -24.9 & -10.3 \\
\hline Western & 18TP84B & 100.3 & 10 & -24.4 & -10.1 \\
\hline Western & 18TP84 & 99.8 & 9 & -24 & -10.1 \\
\hline Western & 18TP83 & 98.8 & 18 & -26 & -10.4 \\
\hline Western & 18TP82 & 98.3 & 8 & -24.1 & -11.3 \\
\hline Western & 18TP81 & 97.6 & 66 & TOC too low & -9.3 \\
\hline Western & 18TP80 & 96.2 & 8 & -25.4 & -9.3 \\
\hline Western & 18TP79 & 94.5 & 24 & -26 & -10 \\
\hline Western & 18TP78 & 93.5 & 25 & TOC too low & -9.6 \\
\hline Western & 18TP77 & 92.2 & 21 & -24.4 & -8.3 \\
\hline Western & $18 T P 76$ & 91.2 & 22 & -25.5 & -8 \\
\hline Western & $18 T P 75$ & 88.8 & 12 & -22.4 & -7.7 \\
\hline Western & 18TP74 & 87.5 & 23 & -24.5 & -6.7 \\
\hline Western & $18 T P 73$ & 86.1 & 28 & -24.9 & -7.3 \\
\hline Western & 18TP72 & 85.3 & 28 & -25 & -6.4 \\
\hline Western & 18TP71 & 84.3 & 26 & -25.2 & - \\
\hline Western & $18 T P 70$ & 83.3 & 27 & -25.2 & - \\
\hline Western & 18TP69 & 82.3 & 26 & -24.8 & - \\
\hline Western & 18TP68 & 81.2 & 23 & -25.8 & - \\
\hline Western & 18TP67C & 81.2 & 27 & -25.5 & -5.8 \\
\hline Western & 18ТР67B & 80.75 & 24 & -26 & -5.7 \\
\hline Western & 18TP67NEW & 80.3 & 28 & -24.3 & -6.2 \\
\hline Western & 18TP67 & 80.3 & 33 & -23.2 & -6.5 \\
\hline Western & 18TP66 & 80 & 25 & -24.6 & -6.8 \\
\hline Western & 18TP65 & 79.4 & 24 & -23.4 & -6.5 \\
\hline Western & 18TP64 & 78.8 & 24 & -22.1 & -6.1 \\
\hline Western & 18TP63 & 78.3 & 22 & -24.6 & -6.6 \\
\hline Western & 18TP62 & 77.9 & 23 & -24.1 & -6.1 \\
\hline Western & 18TP61 & 77.5 & 21 & -24.1 & -6 \\
\hline Western & $18 T P 60$ & 77 & 20 & -24.6 & -6.7 \\
\hline Western & 18TP59 & 76.3 & 24 & -23.6 & -6.1 \\
\hline Western & 18TP58 & 75.3 & 22 & -23.3 & -6.1 \\
\hline Western & $18 T P 57$ & 74.3 & 20 & -23.5 & - \\
\hline Western & 18TP56 & 73 & 19 & -22.3 & -6.2 \\
\hline Western & $18 T P 55$ & 72.5 & 31 & -25.9 & -8.7 \\
\hline Western & 18TP54 & 72.1 & 13 & -24.5 & -9.3 \\
\hline Western & $18 \mathrm{TP} 53$ & 71.1 & 15 & -24.9 & -9.4 \\
\hline Western & $18 T P 52$ & 70.2 & 17 & -24.7 & -9.2 \\
\hline Western & 18TP51 & 69.2 & 20 & -23 & -7.4 \\
\hline Western & $18 \mathrm{TP} 50$ & 68.2 & 23 & -24.5 & -6.6 \\
\hline Western & 18TP49 & 67.3 & 23 & -24.6 & -6.6 \\
\hline Western & $18 \mathrm{TP} 48$ & 66.3 & 21 & -24.2 & -6.6 \\
\hline Western & $18 T P 47$ & 65.1 & 20 & -21 & -6.4 \\
\hline Western & $18 \mathrm{TP} 46$ & 63.8 & 15 & -21.6 & - \\
\hline Western & 18TP45 & 63 & 16 & -21.2 & -5.6 \\
\hline Western & 18TP44 & 61.8 & 21 & -21.1 & -5.5 \\
\hline Western & 18TP43 & 60.2 & 22 & -21.9 & -5.8 \\
\hline Western & 18TP42 & 59.5 & 20 & -21.9 & - \\
\hline Western & 18TP41 & 58.8 & 20 & -24.4 & - \\
\hline Western & $18 \mathrm{TP} 40$ & 58.1 & 24 & -22.7 & -5.8 \\
\hline Western & 18TP39 & 55.9 & 9 & -25.7 & -6.7 \\
\hline Western & 18TP38 & 54.5 & 12 & TOC too low & -7.3 \\
\hline Western & $18 T P 37$ & 53.2 & 16 & -26.3 & -8 \\
\hline Western & 18TP36 & 52.6 & 20 & -25.6 & -8.2 \\
\hline
\end{tabular}

\begin{tabular}{|c|c|c|c|c|c|}
\hline Section & Sample & Height (m) & $\mathrm{CaCO}_{3}(\%)$ & $\begin{array}{c}\delta^{13} C_{\text {org }}(\% \circ)- \\
\text { organics }\end{array}$ & $\begin{array}{c}\delta^{13} C_{\text {nod }}(\%) \\
\text { nodules }\end{array}$ \\
\hline Western & 18TP35 & 51.5 & 18 & -24 & -6.9 \\
\hline Western & 18TP34 & 50.1 & 64 & -25.2 & -8.3 \\
\hline Western & 18TP33 & 49 & 18 & -24.1 & -8.9 \\
\hline Western & 18TP32 & 46.5 & 25 & -23.8 & -6.8 \\
\hline Western & 18TP31 & 45.2 & 24 & -25.9 & -7.4 \\
\hline Western & 18TP30 & 43.8 & 15 & -23.5 & -10.1 \\
\hline Western & 18TP29 & 42.5 & 27 & TOC too low & -7 \\
\hline Western & 18TP28 & 41.4 & 29 & -25 & -6.8 \\
\hline Western & 18TP27 & 40.8 & 19 & -25.8 & - \\
\hline Western & 18TP26B & 39.5 & 8 & -24 & -9.3 \\
\hline Western & 18TP26 & 38.1 & 18 & -24.5 & -10.6 \\
\hline Western & 18TP25 & 37.5 & 20 & -24.6 & - \\
\hline Western & 18TP24 & 36.4 & 14 & -23.5 & - \\
\hline Western & 18TP23 & 34.5 & 19 & -24.6 & - \\
\hline Western & 18TP22B & 33.3 & 15 & -25.1 & - \\
\hline Western & 18TP22A & 33.6 & 13 & -25 & - \\
\hline Western & 18TP21 & 30.8 & 53 & -25.2 & -10.8 \\
\hline Western & $18 T P 20$ & 27.3 & 32 & TOC too low & - \\
\hline Western & 18TP19 & 26.3 & 21 & -24.5 & - \\
\hline Western & 18TP18 & 24 & 30 & TOC too low & - \\
\hline Western & 18TP17 & 21.8 & 27 & -23.8 & - \\
\hline Western & $18 T P 16$ & 20.4 & 15 & -24.6 & - \\
\hline Western & 18TP15 & 18.2 & 12 & -26 & - \\
\hline Western & 18TP14 & 17.5 & 10 & -25.5 & - \\
\hline Western & 18TP13 & 16.9 & 14 & -25.3 & - \\
\hline Western & 18TP12 & 14.4 & 34 & -24.8 & -10.7 \\
\hline Western & 18TP11 & 13 & 65 & -24.1 & -11.2 \\
\hline Western & 18TP10 & 12 & 21 & -25.1 & - \\
\hline Western & 18TP09 & 11.2 & 19 & -24.2 & - \\
\hline Western & 18TP08 & 10.8 & 10 & -25.2 & - \\
\hline Western & 18TP07 & 9.8 & 32 & -25.8 & -8.8 \\
\hline Western & 18TP06 & 8.9 & 27 & -25.8 & -9.8 \\
\hline Western & 18TP05 & 6.5 & 10 & -25.2 & -10.2 \\
\hline Western & 18TP04 & 5 & 8 & -24 & -10.6 \\
\hline Western & 18TP03 & 2.9 & 15 & -24.2 & -10.3 \\
\hline Western & 18TP02 & 1.5 & 10 & -24.6 & -8.7 \\
\hline Western & 18TP01 & 0 & 5 & -24.3 & -7.7 \\
\hline Eastern & 18TP131 & 48.9 & 24 & -26 & -11.1 \\
\hline Eastern & 18TP130 & 47.5 & 13 & TOC too low & -11.8 \\
\hline Eastern & 18TP129 & 46 & 25 & TOC too low & -10.8 \\
\hline Eastern & 18TP128 & 43.9 & 14 & -25.2 & -10.2 \\
\hline Eastern & 18TP127 & 40.5 & 9 & -25.8 & - \\
\hline Eastern & 18TP126 & 39.9 & 11 & -25.8 & -11.8 \\
\hline Eastern & 18TP125 & 38.1 & 8 & -25.5 & - \\
\hline Eastern & 18TP124 & 34.9 & 11 & -24.7 & - \\
\hline Eastern & 18TP123 & 32 & 9 & -25.2 & - \\
\hline Eastern & 18TP122 & 30.5 & 10 & -25.7 & - \\
\hline Eastern & 18TP121 & 28.8 & 12 & -25.1 & - \\
\hline Eastern & 18TP 120 & 28.3 & 13 & -26 & -10.8 \\
\hline Eastern & 18TP119 & 27.9 & 32 & -26.9 & - \\
\hline Eastern & 18TP118 & 26.6 & 30 & -25.7 & - \\
\hline Eastern & 18TP117 & 23.5 & 24 & TOC too low & - \\
\hline Eastern & 18TP116 & 21.7 & 9 & -25.7 & -9.2 \\
\hline Eastern & 18TP115 & 19.8 & 10 & -24.5 & - \\
\hline Eastern & 18TP114 & 17.2 & 10 & -24.7 & -9.9 \\
\hline Eastern & 18TP113 & 15.4 & 5 & -25 & - \\
\hline Eastern & 18TP112 & 13.5 & 5 & TOC too low & - \\
\hline Eastern & 18TP111 & 11.5 & 6 & -24 & - \\
\hline Eastern & 18TP110 & 10.5 & 18 & -22.7 & - \\
\hline Eastern & 18TP109 & 9.5 & 13 & -24.4 & -9.6 \\
\hline Eastern & 18TP108 & 8.9 & 11 & -23.8 & -7.5 \\
\hline Eastern & 18TP107 & 8.1 & 10 & -23.5 & -8 \\
\hline Eastern & 18TP106 & 6.7 & 13 & -23.2 & - \\
\hline Eastern & 18TP105 & 5.2 & 11 & -25.2 & - \\
\hline Eastern & 18TP104 & 4.5 & 22 & -24.3 & -10.1 \\
\hline Eastern & 18TP103 & 4 & 12 & -24.6 & -10.2 \\
\hline Eastern & 18TP102 & 1.8 & 19 & -24.2 & -9.5 \\
\hline Eastern & 18TP101 & 0.2 & 13 & -25.2 & -9.6 \\
\hline
\end{tabular}


Table 1. Chemostratigraphical data of the Shapaja area, including section, sample labels, heights (m), $\mathrm{CaCO}_{3}$ content (\%), $\delta^{13} \mathrm{C}_{\text {org }}$ values (\%, VPDB) and $\delta^{13} \mathrm{C}_{\text {nod }}$ values (\%o, VPDB).
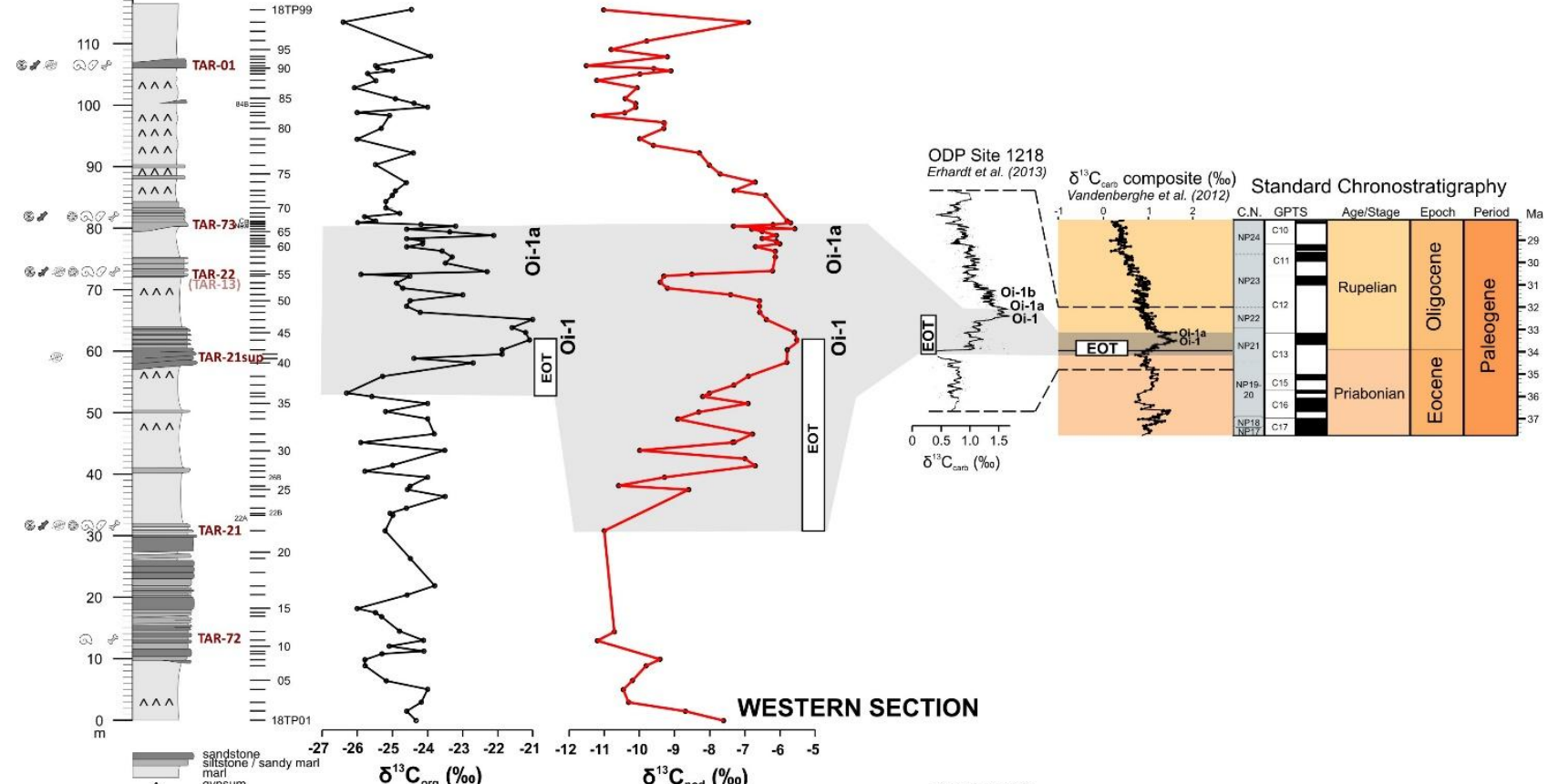

$\delta^{13} \mathrm{C}_{\text {cond }}(\%)$
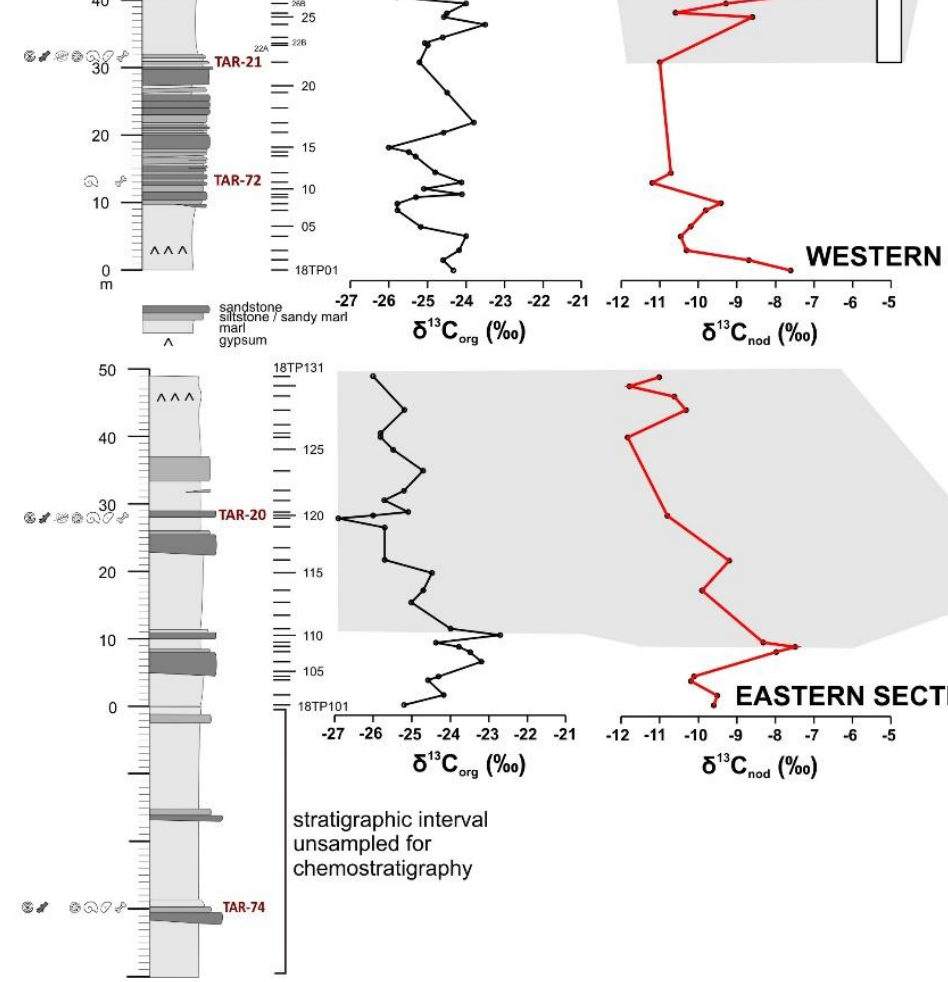

WESTERN SECTION

Fig. 2. Stratigraphic sections encompassing the late Eocene-early Oligocene interval at Shapaja, with location of chemostratigraphical samples, resulting $\delta^{13} \mathrm{C}$ curves (on organic matter $\left[\delta^{13} \mathrm{C}_{\text {org }}\right.$ ] and pedogenic carbonate nodules $\left[\delta^{13} \mathrm{C}_{\text {nod }}\right]$, in \%o), and chronological interpretations (right) based on ${ }^{13} \mathrm{C}$ curves around the Eocene-Oligocene transition in ODP Site 1218 (Erhardt et al., 2013) and reference $\delta^{13} \mathrm{C}$ composite curve (Cramer et al., 2009 modified by Vandenberghe et al., 2012). Top = western section; bottom = eastern section. Ideograms denote fossil content (charophytes, wood, leaf imprints, seeds/fruits, mollusks, crustaceans, and vertebrates, respectively; see Fig. 1). C.N., Calcareous Nannoplankton. EOT, Eocene-Oligocene Transition. GPTS, geomagnetic polarity timescale.

\subsection{Plant remains}

4.2.1 Leaf and fruit impressions (Fig. $3 \mathrm{~A}-\mathrm{H}$ )

Ten magnoliopsid dicot morphotypes were recognized in the Shapaja section, through leaf and fruit impressions (nine morphotypes and one [PZ4], respectively), recovered from TAR-20 (late 
Eocene), TAR-21sup (EOT), and TAR-01 (early Oligocene). Most morphotypes are documented by several specimens. These morphotypes are fully described, compared, and illustrated in the SI. TAR-20 yielded a single leaf morphotype (PZ5; Fig. S1M) and TAR-21sup three (PZ1-3; Fig. 3A-C), all of uncertain affinities. TAR-01 provided by far the most diversified macroflora, with a fruit morphotype (PZ4: legume; Fig. 3D) and seven leaf morphotypes (PZ1, PZ3, PZ6-10; Fig. 3E-G). Three of them document Fabaceae Fabales (PZ4, 8, and 9). Leaf morphotypes PZ1 and PZ3 were recognized both at TAR-21sup and TAR-01.

All leaves from the Shapaja section have entire margins and pinnate primary venation. Most have nanophyll and/or microphyll leaflet laminar sizes (dimorphic leaflets in PZ10; Fig. 3F), with petiolate leaf and marginal blade attachments. PZ1 and PZ2 have larger leaflets (mesophyll and notophyll, respectively; Fig. 3A,C). Some leaves are compound pinnae or bipinnate, imparipinnate with opposite (PZ8; Fig. 3F) or alternate (PZ9; Fig. 3G), non-overlapping pinnules. The leaves/leaflets are either oblong, obovate, ovate, or elliptic in shape (PZ9), mostly with an acute apex. Major secondaries are brochidodromous in most morphotypes, except for PZ6 and PZ8 (craspedodromous). PZ2 has affinities with the late Miocene morphotype IP2 from Shumanza (Feussom-Tcheumeleu et al., 2019) and with Machaerium (Fabaceae). All four fruit specimens available at TAR-01 are straight and symmetric legumes, with placental and non-placental margins (well-developed, but very narrow and non-winged), seven symmetrical seminal chambers separated by a septum, and a convex apex (Fig. 3D). 


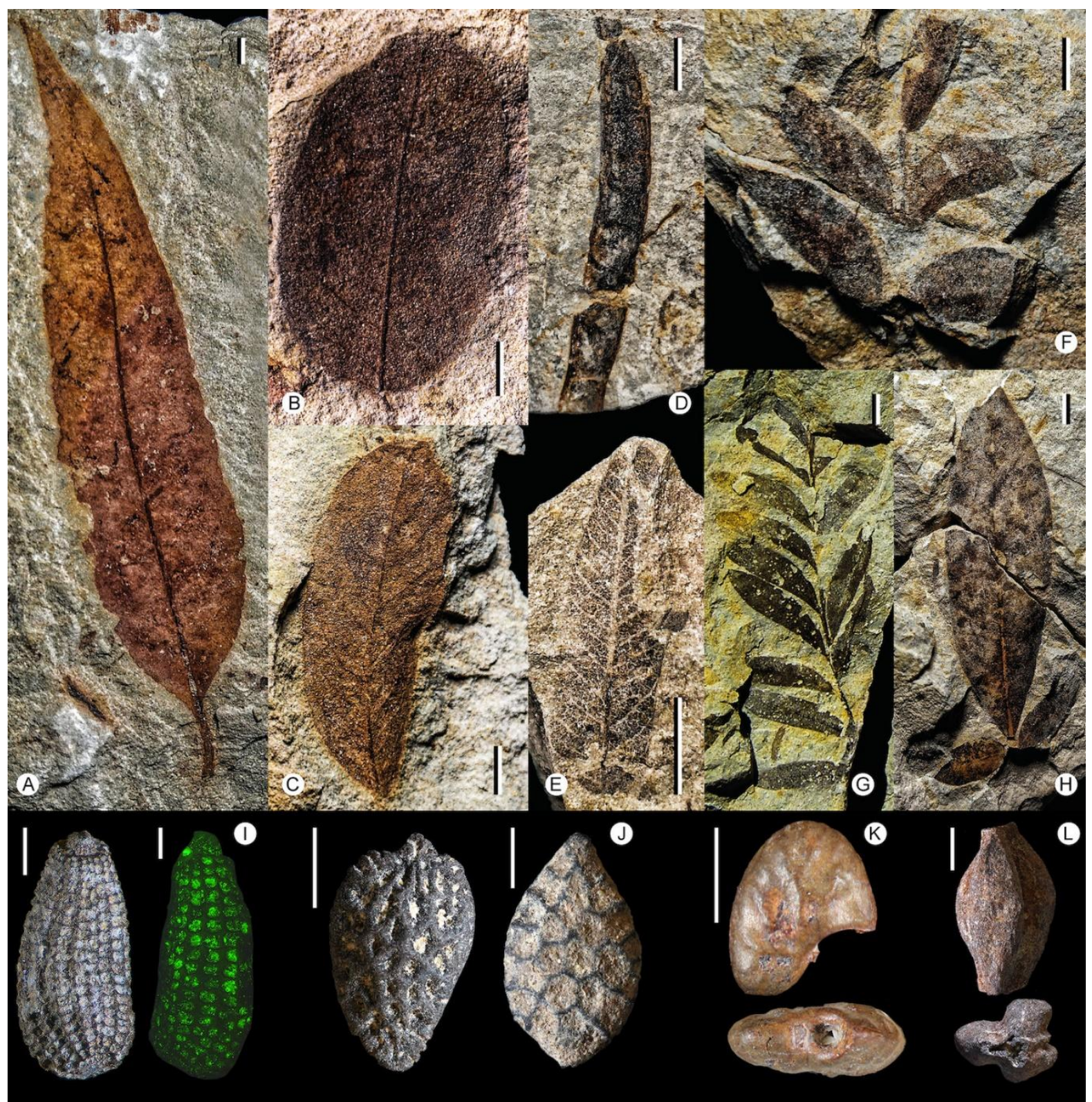

Fig. 3. Plants (leaf and fruit impressions; permineralized seeds and fruit) from the late Eoceneearly Oligocene Shapaja section, San Martín, Peruvian Amazonia. A, PZ1, non-monocot of uncertain affinities (PVMUSM-60; TAR-21sup). B, PZ2, non-monocot of uncertain affinities, resembling Fabaceae (PVMUSM-66; TAR-21sup). C, $P Z 3$, non-monocot of uncertain affinities (PVMUSM-68; TAR-21sup). D, PZ4, Fabaceae fruit (PVMUSM-71; TAR-01). E, PZ7, non-monocot of uncertain affinities (PVMUSM-78; TAR-01). F, PZ8, Fabaceae compound leaf (PVMUSM-80; TAR01). G, PZ9, compound leaf of uncertain affinities (PVMUSM-82; TAR-01). H, PZ10, non-monocot of uncertain affinity (PVMUSM-83; TAR-01). I, cf. Elatine seeds showing reticulate seed coats, left (TAR-74), right (TAR-01) photographed under epifluorescence. J, Two Passifloroideae seed types showing conspicuously pitted surfaces (TAR-21). K, Araceae (cf. Monstera) seed; top in lateral view, bottom in ventral view, note depressed hilum (TAR-21). L, Loculicidal fruit of euphorbiaceous affinity. Scale bars $=5 \mathrm{~mm}(\mathrm{~A}-\mathrm{H}), 2 \mathrm{~mm}$ (J left, L), $1 \mathrm{~mm}$ (J right, K), and $500 \mu \mathrm{m}(\mathrm{I})$.

\subsubsection{Seeds}

Approximately forty seeds were identified throughout the Shapaja section. However, most of the specimens came from late Eocene samples, particularly from locality TAR-21. Seeds that were taxonomically identified are briefly described here. 
- cf. Elatine (TAR-74, TAR-01): two small seeds ( $600-700 \mu \mathrm{m}$ long), slightly curved, operculate, with reticulate coat (Fig. 3I).

- Passifloroideae (TAR-21): two different seed morphotypes of the passion fruit family were identified from TAR-21. Both seeds are bilateral, ellipsoidal to ovoid with a rounded base and a pointed apex, chalaza apical, and a conspicuously pitted surface (>20 depressions) (Fig. 3J).

- Araceae (cf. Monstera): The most common seed morphotype from the Shapaja section, with 30 specimens. The seeds are $\sim 2 \mathrm{~mm}$ high and $2.5 \mathrm{~mm}$ wide, flattened ventrally and with a dorsal ridge, the micropyle is on the opposite side of the hilum from the chalaza. The hilum appears as a depressed channel (Fig. 3K).

Three other seeds are less understood due to their fragmentary preservation and will require additional study to confirm their affinity, but they can be preliminarily assigned to the families Vitaceae (TAR-20), Poaceae (TAR-20), and Nymphaceae (TAR-73). A single loculicidal fruit of euphorbiaceous affinity is also reported from sample TAR-21 (Fig. 3L).

\subsubsection{Charophytes and wood.}

All localities but TAR-72, TAR-21sup, and TAR-13 have yielded charophyte oogonia and wood chunks (millimetric to centimetric, either silicified or oxidized). They were not identified thus far.

\subsubsection{Pollen.}

Several samples were processed but they were all sterile with the exception of a sample at TAR72, i.e., 12 stratigraphic meters below TAR-21 (latest Eocene). The TAR-72 sample had a poor recovery of organic matter mostly dominated by coaly matter and a few grains that include the magnoliopsid Psilatricolporites sp., Fungi monocellate, and the fern spores Psilatriletes $\mathrm{sp}$. and Baculatriletes sp. The high level of organic matter degradation suggests a seasonal water-table that oxidized the organic matter.

\subsection{Mollusks and decapods}

Mollusks are mostly represented by freshwater gastropod inner casts, with two distinct species of small pachychilids (TAR-01; tropical distribution; Fig. 5A), three specimens of a small planorbid (Helisoma sp.; one in TAR-20, two in TAR-21), several ampullariids either large or small (TAR-22; Fig. 4C), and small unidentified turriform snails (TAR-20, TAR-72, and TAR-73), and a bulliform snail of unknown affinities (two specimens in TAR-21; Fig. 4D). An external cast of a pluricentimetric bivalve with paired valves, referred to as a probable corbiculid of freshwater-brackish affinities, was unearthed at TAR-22 (Fig. 4A-B).

Decapod claw and carapace fragments were found by hundreds in most localities (TAR-74, TAR-20, TAR-21, TAR-13, TAR-22, TAR-73, and TAR-01). All of them are assigned to Trichodactylidae, a South and Central American family of freshwater crabs of tropical affinities, abundant in Amazonian lowland streams today (Yeo et al., 2008), but with a scarce fossil record ranging the middle Eocene-late Miocene in Western Amazonia (Klaus et al., 2017). None of the specimens from the Shapaja decapod sample, partly studied by Klaus et al. (2017) for the TAR-01 locality, is identifiable at the genus or species level.

\subsection{Vertebrates:}

\subsubsection{Metatherian mammals}

Two fragmentary dental remains from TAR-74 and TAR-01, preventing precise taxonomic identification (Fig. 4E), and a 1-mm wide astragalus (Fig. 5B-D) are referred to as Marsupialiformes incertae sedis.

The extinct order Polydolopimorphia is represented in Shapaja by five taxa assigned to Bonapartheriiformes. Aside from a new prepidolopid bonapartherioid documented at TAR-74 (Fig. 
4F-G), at least two taxa are assigned to argyrolagid argyrolagoids. The affinities of argyrolagids (gerbil-like marsupials) are still under debate. There is evidence supporting Argyrolagidae as representatives of polydolopimorphians (Goin et al., 2009; Chornogubsky \& Goin, 2015) and of paucituberculatans (Sánchez-Villagra, 2001; Beck, 2017); in addition, a recent phylogeny indicates that argyrolagids are not paucituberculatans, and that they are phylogenetically close to peramelemorphs (Abello and Candela, 2020). Nonetheless, this discussion is out of the scope of this study, so we will assign here argyrolagids to ?Polydolopimorphia. Fragmentary and heavilyworn molars from TAR-20 and TAR-72 (late Eocene) are identified as cf. Proargyrolagus. In contrast, specimens from TAR-21 (latest Eocene) and TAR-01 (early Oligocene) are well preserved and abundant (upper and lower cheek teeth). They document two distinct new species of Proargyrolagus: a small species in TAR-21 ( $P$. nov. sp. A; Fig. 4H-J) and a larger one in TAR-01 ( $P$. nov. sp. B; Fig. 5E-F). Accordingly, the Shapaja section attests to the earliest occurrence of $i$ ) Proargyrolagus, previously from upper Oligocene Salla Beds, Bolivia (Wolff, 1984; Sánchez-Villagra \& Kay, 1997), and ii) the earliest and northernmost occurrences of Argyrolagidae, further pointing to the unsuspected and long-termed presence of these unique metatherians throughout the Eocene-Miocene interval in Proto-Amazonia (see Antoine et al., 2016). These teeth are "protohypsodont" (i.e., high-crowned) and complete specimens retain closed roots. Unidentifiable plagiaulacoid premolars are also recognized in TAR-20, TAR-72 (late Eocene) and TAR-01 (early Oligocene), and assigned to polydolopimorphians of uncertain affinities. 

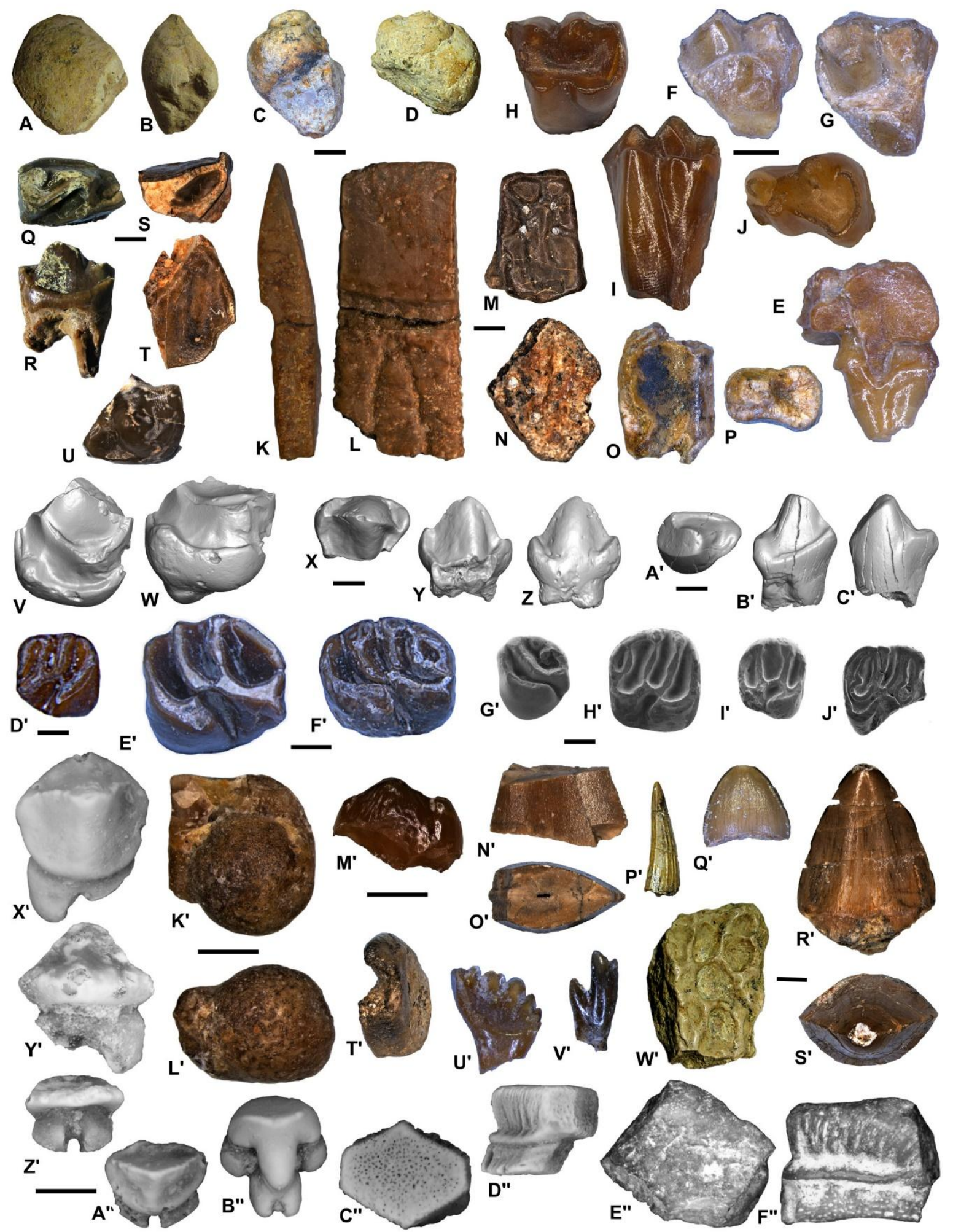

Fig. 4. Representative faunal content of late Eocene-earliest Oligocene paleocommunities near Shapaja, San Martín, Peruvian Amazonia (Assemblages 1 and 2; see Tables 2-4). A-B, MUSM 3955, Corbiculidae indet., natural inner cast with joined valves, in lateral (A) and dorsal views (B), TAR22. C, MUSM 3956, Gastropoda indet., natural inner cast in front view, TAR-22. D, MUSM 3957, Gastropoda indet., bulliform, natural inner cast in front view, TAR-22. E, MUSM 3958, Marsupialiformes incertae sedis, left P3 in labial view, TAR-74. F-G, MUSM 3959, Prepidolopidae gen. et sp. nov., right $M x$ in lingual (F) and occlusal views (G), TAR-74. H-J, Proargyrolagus nov. sp. A, TAR-21: MUSM 3960, left M2 in occlusal (H) and lingual views (I); MUSM 3961, left m1 in occlusal view (J). K-M, Parastegosimpsonia peruana: MUSM 3962, mobile osteoderm in cross (K) 
and lateral views (L), TAR-21; MUSM 3963, fixed osteoderm in external view (M), TAR-22. N, MUSM 3964, Peltephilidae indet., fixed osteoderm, TAR-21. O-P, MUSM 3965, Mylodontidae indet., molariform in lateral (O) and vertical views (P), TAR-22. Q-R, MUSM 3966, Leontiniidae indet., right p3 in occlusal (Q) and labial views (R), TAR-74. S-T, MUSM 3967, Adianthidae indet., fragmentary right M2-3 in occlusal (S) and lingual views (T), TAR-21. U, MUSM 3968, Didolodontidae indet., fragment of a left ?m1 in occlusal view, TAR-22. V-W, MUSM 3969, Anthropoidea indet. 1, right upper molar fragment in occlusal (V) and lingual views (W), TAR-21. XC', Anthropoidea indet. 2 (small) TAR-21: MUSM 3970, right upper premolar (labial part) in occlusal (X), lingual (Y), and labial views (Z); MUSM 3971, left p2 in occlusal ( $\left.A^{\prime}\right)$, lingual ( $\left.B^{\prime}\right)$, and labial views (C'). D', MUSM 3972, Pozomys nov. sp., left $m 1$ in occlusal view, TAR-74; E'-F', Eopululo cf. wigmorei, TAR-74: E', MUSM 3973, left M1/2 in occlusal view; F', MUSM 3974, left dP4 in occlusal view. G', MUSM 2965, Eoincamys parvus, left M3 in occlusal view, TAR-22. H', MUSM 2925, Kichkasteiromys raimondii, right M1/2 (holotype) in occlusal view, TAR-21. I', MUSM 2960, Selvamys paulus, right M2 in occlusal view, TAR-22; J', MUSM 3332, Tarapotomys subandinus, fragmentary right M1 in occlusal view, TAR-20. $\mathbf{K}^{\prime}-\mathrm{L}^{\prime}$, MUSM 3975, Anura indet., distal humerus in anterior ( $\mathrm{K}^{\prime}$ ) and distal views ( $\left.\mathrm{L}^{\prime}\right)$, TAR-20. $\mathbf{M}^{\prime}$, MUSM 3976, unidentified ?teiid squamate tooth in lateral view, TAR-21. N'-0', MUSM 3977, Sebecidae indet., fragmentary tooth in lingual ( $N^{\prime}$ ) and apical views (O'), TAR-74. P', MUSM 3978, Gavialoidea indet., tooth in sagittal view, TAR-22. Q', MUSM 3979, Caimaninae indet., globular tooth in lingual view, TAR-22. R'-S', MUSM 3980, Caimaninae indet., leaf-shaped tooth in lingual $\left(R^{\prime}\right)$ and apical views $\left(S^{\prime}\right)$. $T^{\prime}, M U S M$ 3981, Lepidosirenidae indet., large dental plate in apical view, TAR-72. U', MUSM 3982, Anostomidae, cf. Leporinus sp., hexacuspid tooth, TAR-21. V', MUSM 3983, Loricariidae indet., muffle-shaped tooth, TAR-21. W', MUSM 3984, cf. Phractocephalus sp., fragmentary cranial bone, TAR-22. $X^{\prime}-Y^{\prime}$, MUSM 3985, Paratrygon nov. sp., female anterior tooth in lingual $\left(X^{\prime}\right)$ and labial views ( $\left.Y^{\prime}\right)$, TAR-22. $Z^{\prime}-A^{\prime \prime}$, MUSM 3986, Potamotrygon nov. sp., female anterior tooth in lingual ( $\left.Z^{\prime}\right)$ and labial views (A"), TAR-21. B", MUSM 3987, Pristis sp., oral tooth in lingual view, TAR-22. C"-D", MUSM 3988, Myliobatis sp., tooth of a neonate/young individual in occlusal ( $\left.C^{\prime \prime}\right)$ and lateral views (D"), TAR-21. E"-F", MUSM 3989, ?Myliobatis sp., tooth in occlusal ( $\left.E^{\prime \prime}\right)$ and lateral views (F"), TAR21. $V-C^{\prime}$ are 3D surface renderings. Scale bars $=500 \mu \mathrm{m}\left(E-J, V-D^{\prime}, G^{\prime}-L^{\prime}, U^{\prime}-V^{\prime}, E^{\prime \prime}-F^{\prime \prime}\right), 1 \mathrm{~mm}\left(E^{\prime}-F^{\prime}\right.$, $\left.M^{\prime}-O^{\prime}, X^{\prime}-D^{\prime \prime}\right), 2 \mathrm{~mm}\left(C, K-P, S-U, Q^{\prime}-T^{\prime}\right), 5 \mathrm{~mm}\left(D, Q-R, P^{\prime}\right)$, and $10 \mathrm{~mm}(A-B)$.

Paucituberculata (shrew opossums) are the most diverse order in Shapaja, with at least 12 taxa, all belonging to the extinct superfamily Palaeothentoidea (Fig. 5G-I). The records from Shapaja encompass two primitive species of Non-Pichipilidae palaeothentoids (NPP) in uppermost Eocene levels (TAR-72 and TAR-21), one of them being close to Perulestes, previously described at Santa Rosa (Goin \& Candela, 2004) with close allies in early Contamana faunas (Antoine et al., 2016). Representatives of Palaeothentidae and Abderitidae are much more diversified in TAR-01 (early Oligocene; Fig. 5I). In addition, fragmentary remains from TAR-72 and TAR-21 and referred to Palaeothentinae might document the earliest occurrence of the subfamily, previously recorded in the late Oligocene of Argentina and Bolivia (Abello, 2007; Rincón et al., 2015). Contrary to all other localities, TAR-13 and TAR-22 have yielded a single marsupialiform specimen (a tiny astragalus of an unidentified marsupialiform [Fig. 5B-D] and a palaeothentoid molar, respectively; Table 2). This low abundance is particularly striking with respect to the volume of sediment treated at TAR-22 (214 kg; see SI). No metatherian specimen was recognized at TAR-73.

\subsubsection{Eutherian mammals.}

Cingulates (armadillos). Two osteoderms (one movable and one fixed) from TAR-21 and TAR-22 described at Santa Rosa (Ciancio et al., 2013). Two other osteoderms are too eroded/fragmentary 
for a precise identification but attributable to the Peltephilidae (TAR-21; Fig. 4N) and Dasypodidae 462 (TAR-01) families.

463 Pilosans (sloths). A molariform belonging to a small mylodontid (under study by FP) was recovered from TAR-22 (Fig. 40-P). Smaller in size than the smallest known representative of the family (Brievabradys laventensis, middle Miocene of Colombia; Villarroel, 2000), this " 8 "-shaped tooth is somewhat reminiscent to last upper molariforms of the late Oligocene Octodontotherium and Paroctodontotherium (Deseadan of Argentina and Bolivia, respectively; Hoffstetter, 1956; Shockey et al., 2011). Excluding Pseudoglyptodon (an Oligocene sloth-like xenarthran of dubious affinities; McKenna et al., 2006), this fossil from TAR-22 likely stands as the oldest record of a true sloth (for a review, see Pujos et al., 2017).

As for Astrapotheria (elephant-like native ungulates), the occurrence of unidentified Astrapotheriidae is suspected in TAR-21 and TAR-01, through small fragments of large-sized cheek teeth with apparent vertical and horizontal decussation on enamel (Koenigswald, 1997).

Among Notoungulata, representatives of the suborders Toxodontia (horse- and rhino-like native ungulates) and Typotheria (rabbit-like native ungulates) were recognized throughout the section, on the basis of isolated teeth and tooth fragments. Unfortunately, most remains are fragmentary and not assignable at the family level or below. Toxodontia indet. are documented by fragments of large-sized teeth (TAR-74, TAR-20, and TAR-01). An early-diverging leontiniid occurs in TAR-74, as recorded by a mesodont lower premolar ( $\mathrm{p} 3$; length $=16 \mathrm{~mm}$; width $=11 \mathrm{~mm}$; Fig. 4Q-R) with a strong distolabial extension of the protolophid, a bunoid entoconid united to the hypolophid, a short entolophid, an un-isolated fossettid, and a talonid longer than the trigonid. Somewhat reminiscent of p3-4 of Elmerriggsia from Deseadan beds of Patagonia (e.g., Shockey et al., 2012), it is much closer morphologically to the p3 of Scarrittia barranquensis, from La Cantera (early Oligocene, Patagonia; Ribeiro et al., 2010), from which it only differs in being $30 \%$ smaller and $40 \%$ narrower. Typotheria may have been more diversified than toxodonts, with two distinct bispecific faunas, in TAR-74 and TAR-22. More precisely, TAR-74 (late Eocene) yields a small hypsodont cheek tooth fragment, with cement, pointing to an unidentified interatheriid or hegetotheriid and low-crowned tooth fragments of a small unidentified typothere (morph 1). This morph 1 also likely occurs in TAR-21. In TAR-22 (earliest Oligocene), a medium-sized molar fragment, hypsodont, with a closed fossette/fossettid and a wide enamel band, is assignable to a late "archaeohyracid" (Archaeohyrax, Archaeotypotherium, or Protarchaeohyrax), while smaller-sized low-crowned fragmentary teeth (decidual teeth?) may document another typothere referred to as "Archaeohyracidae" indet. A $14 \mathrm{~mm}$-long lower tooth from TAR-73, eroded and heavily worn, has diverging roots. It is assigned to Notoungulata indet.

Litopterna (horse- and camel-like native ungulates) are not abundant in the Shapaja section. At TAR-21, the mesiolabial tip of a right upper molar documents an adianthine adianthid (Fig. 4S-T). The corresponding tooth is low-crowned, with a sharp and labially-protruding parastyle, a shallow oblique fossette, a smooth labial cingulum, thin enamel, and a saddle-shaped neck both lingually and labially. Its morphological pattern closely resembles that of M2-3s of Tricoelodus from Deseadan beds of Argentina and Bolivia (Cifelli \& Soria, 1983), but with a size 50\% larger than in both species assigned to Tricoelodus. This specimen likely fills a stratigraphic gap between the Eocene indalecines and the late Oligocene adianthines, only occurring at mid-and high latitudes (Cifelli \& Soria, 1983).

We refer to a tooth fragment as an unidentified didolodontid (TAR-22; Fig. 4U). This pristine specimen preserves the distolingual part of a left lower molar (probably $\mathrm{m} 1$ ), of brachydont and bunodont condition. It has a prominent and conical entoconid, a much thinner and lower hypoconulid with a low postentocristid joining them, and a marked postentocingulid between both cuspids. Such morphological features closely resemble those of the $\mathrm{m} 1$ of Didolodus from the 
510 late middle Eocene of Patagonia (e.g., Simpson, 1967), the latter being $15 \%$ larger than the 511 Shapaja specimen. It is much larger than Ernestokokenia and Saltaodus (Gelfo et al., 2019). Direct comparison with Sallalodus deutherotherioides is not possible, as its original hypodigm is restricted to two associated upper molars, larger sized than the specimen from TAR-22 (Soria \& Hoffstetter, 1983).

Pyrotheria (mastodon-like native ungulates) are documented at Shapaja by tooth fragments with a lophodont Bauplan, thick enamel with vertically-oriented bands (Von Koenigswald et al., 2014), and a typical sagittally-oblique wear pattern. They are tentatively assigned either to Pyrotheria indet. (TAR-20 and TAR-21; latest Eocene) or to the pyrotheriid cf. Griphodon sp. (TAR-13, TAR-22, and TAR-01; earliest Oligocene) when their features and dimensions match closely those of Griphodon. Griphodon peruvianus was originally described in Paleogene deposits from the vicinity of Shapaja (probably Eocene in age; Anthony \& Richards, 1924; Patterson, 1942). Other tooth fragments were assigned to unidentified native ungulates (TAR-72).

Chiropterans (bats). Distolabial fragments of two hyperdilambdodont upper molars from TAR-21 and TAR-01 (estimated length $<2 \mathrm{~mm}$ ) are assignable to unidentified chiropterans (Chiroptera indet.).

Primates (monkeys). In the Shapaja section, primates have so far been found only at TAR-21. Despite the large amount of sediment sampled and treated by wet screening, the fossil material documenting primates is particularly rare compared to that of metatherians or rodents from the same locality (see specific paragraphs). It consists of five dental remains, most of which are fragmentary (a well-preserved trigon region of an upper molar [Fig. 4V-W], an upper molar fragment, the buccal part of an upper premolar [Fig. 4X-Z], a complete but worn lower second premolar [Fig. $4 \mathrm{~A}^{\prime}-\mathrm{C}^{\prime}$ ], and a worn lower molar). These fossils attest to the co-occurrence of at least two tiny but size-distinct species. Pending the discovery of new specimens, the paucity and fragmentary nature of the currently available material does not allow evaluating the phylogenetic affinities of these two species. However, despite the scarce morphological information, the lingual part of a half upper molar displays a complete and quite strong lingual cingulum, with a minute but well-defined hypocone, without a pre-hypocrista (Fig. 4W). Such a simple pattern illustrates, to some extent, the degree of primitiveness of that primate, which rather matches that of some basal anthropoids from the Paleogene of Africa and Perupithecus from Santa Rosa (early Oligocene; Bond et al., 2015; Seiffert et al., 2020) or even Parvimico from Madre de Dios (early Miocene; Kay et al., 2019) than that of most subsequent stem and/or crown platyrrhines of South America (i.e., Homunculidae and extant families; for details, see Marivaux et al., 2016).

Rodents are by far the most conspicuous and species-rich mammalian group in the Shapaja section, with teeth uncovered in all localities, and $c a .500$ specimens identified taxonomically. TAR-21 and TAR-01 yielded most rodent material. This material was extensively described in Boivin et al. (2018, 2019a, 2019b) and we only provide here an updated overview, including additional specimens from the last field campaigns (2018-2019). Twenty-two distinct caviomorph taxa document stem Caviomorpha (sensu Boivin et al., 2019a), representatives of three extant superfamilies (i.e., Chinchilloidea [chinchillas], Erethizontoidea [New World porcupines], and Octodontoidea [spiny rats]; Table 3), and caviomorphs of uncertain affinities. Caviomorphs from the Shapaja localities notably display a well-marked disparity regarding crown height, as brachydont, mesodont, and subprotohypsodont / protohypsodont morphs are recognized (Boivin et al., 2018). Although small-sized rodents widely predominate in the Shapaja section, specimens attesting to the presence of larger-sized taxa were found in late Eocene localities such as TAR-74 (Eopululo cf. wigmorei; Fig. 4E'-F') and TAR-21 (Caviomorpha gen. et sp. indet. 5), and in the 
earliest Oligocene TAR-22 locality (Caviomorpha gen. et sp. indet. 2). In terms of taxonomic richness, the most diversified rodent fauna from Shapaja is recorded at TAR-21 (with eight cooccurring species), followed by TAR-22 (six, including Selvamys paulus [Fig. 4I']), TAR-01 and TAR20 (five), TAR-74 and TAR-13 (four), and lastly TAR-72 (two). The earliest rodent fauna (TAR-74: Assemblage 1 ) is fully distinct from all younger ones. It includes a new representative of Pozomys (Fig. 4D'), a genus originally restricted to late middle Eocene localities of Contamana (Boivin et al., 2017) and recognized at Santa Rosa (Arnal et al., 2020). It also yields Eopululo cf. wigmorei, i.e. a close ally of a species defined at Santa Rosa (Frailey \& Campbell, 2004), a taxon tentatively approximated to Eoincamys (a stem chinchilloid, distinct from that of TAR-13), and an unidentified caviomorph. Overlying localities yield quite homogenous rodent faunas over the TAR-20 to TAR-22 interval, with genera and/or species in common, especially among Eoincamys and Tarapotomys (Assemblage 2; Table 3): Eoincamys valverdei occurs in all localities from this interval; Eoincamys parvus is recognized at TAR-20, TAR-21, and TAR-22 (Fig. 4G'); Tarapotomys subandinus is documented in all localities, except in TAR-13 (Fig. 4J'); Caviomorpha nov. gen. et sp. ranges from TAR-20 to TAR-13, and an unidentified caviomorph (Caviomorpha gen. et sp. indet. 1) occurs at TAR-20 and TAR-21. The early erethizontoid Kichkasteiromys raimondii is restricted to TAR-21 (Fig. $4 \mathrm{H}^{\prime}$ ). Conversely, the uppermost locality of the section (TAR-01) provides a very distinctive fauna, with Tarapotomys mayoensis, Shapajamys labocensis, Mayomys confluens, Eoincamys cf. pascuali, and an unidentified chinchilloid (Assemblage 3; Table 3; Fig. 5J-M). Moreover, only five rodent species are recognized at TAR-01, which is a strikingly low taxonomic diversity with respect to the number of specimens uncovered (406 cheek teeth) and to the volume of sediment treated (470 $\mathrm{kg}$; see SI).

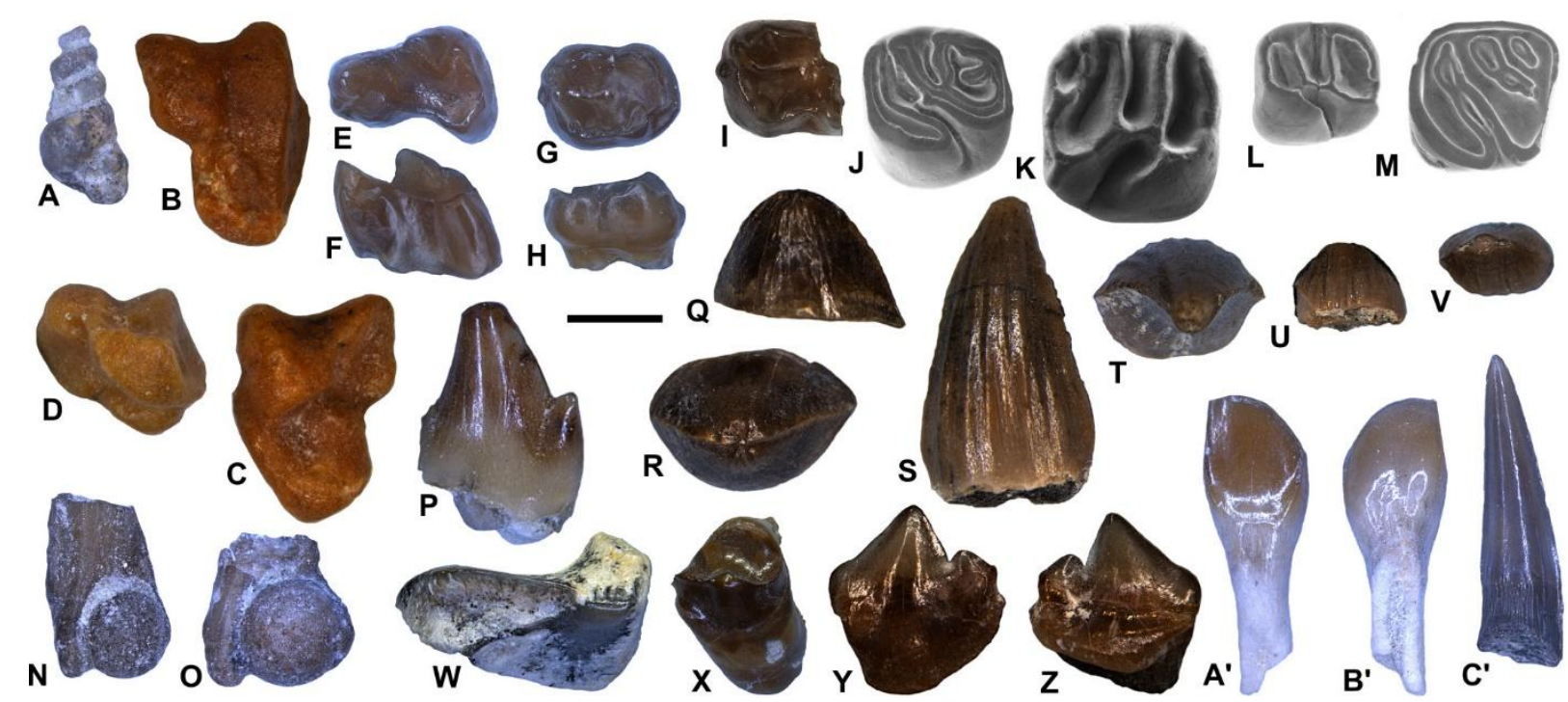

Fig. 5. Representative faunal content of the early Oligocene paleocommunities near Shapaja, San Martín, Peruvian Amazonia (Assemblage 3; see Tables 2-4). All specimens originate from TAR-01, except for MUSM 4018 (B-D: TAR-13). A, MUSM 3990, Pachychilidae indet. sp. 2, natural inner cast in front view. B-D, MUSM 4018, Marsupialiformes incertae sedis, right astragalus in dorsal (B), plantar (C) and distal views (D). E-F, MUSM 3991, Proargyrolagus nov. sp. B, left $m 1$ in occlusal (B) and labial views (C). G-H, MUSM 3992, Palaeothentoidea indet. 2, right ?m4 in occlusal (D) and lingual views (E). I, MUSM 3993, Abderitidae indet., fragmentary right $\mathrm{m} 2$, in occlusal view. J, MUSM 3496, Tarapotomys mayoensis, left M2 (holotype) in occlusal view. K, MUSM 2995, Shapajamys labocensis, right M2 (holotype) in occlusal view. L, MUSM 3159, Mayomys confluens, left M1 in occlusal view. M, MUSM 3492, Eoincamys cf. pascuali, right m1 in occlusal view. N, MUSM 3994, Anura indet., distal humerus fragment in anterior view. O, MUSM 3995, Anura indet., non-Pipidae, distal humerus fragment in anterior view. P, MUSM 3996, Unidentified 
squamate tricuspid tooth in lingual view. Q-R, MUSM 3997, Caimaninae indet., broken tooth, with irregular enamel in labial (N) and apical views (O). S-T, MUSM 3998, Caimaninae indet., tooth with grooved enamel in labial (P) and apical views (Q). U-V, MUSM 3999, Caimaninae indet., durophagous tooth, in labial (R) and apical views (S). W, MUSM 4000, Lepidosirenidae indet., large dental plate. X, MUSM 4001, cf. Colossoma sp., tooth in apical view. Y-Z, MUSM 4002, cf. Serrasalmus sp., $4^{\text {th }}$ or $5^{\text {th }}$ tooth of the dentary, in labial (V) and lingual views (W). $A^{\prime}-B^{\prime}$, MUSM 4003, Leporinus sp., tooth in palatine (X) and ab-palatine views (Y). $C^{\prime}$, MUSM 4004, Hydrolycus sp., tooth in lingual view. Scale bar $=500 \mu \mathrm{m}(\mathrm{B}-\mathrm{D}), 1 \mathrm{~mm}(\mathrm{E}-\mathrm{P}, \mathrm{U}-\mathrm{V}, \mathrm{Y}-\mathrm{Z})$ and $2 \mathrm{~mm}(\mathrm{~A}, \mathrm{Q}-\mathrm{T}, \mathrm{W}-\mathrm{X}$, $\left.A^{\prime}-C^{\prime}\right)$.

\subsubsection{Anurans (frogs)}

A dozen of postcranial elements of very small dimensions were recovered in four localities over the studied section. All of them are of uncertain taxonomic affinities. They consist of fragmentary humeri (TAR-74, TAR-20 [Fig. 4K'-L'], and TAR-01 [two morphs, including non-Pipidae; Fig. 5N-O]), radio-ulnae (TAR-20, TAR-21, and TAR-01), and ilium (TAR-01).

\subsubsection{Squamates (lizards)}

Isolated millimetric tricuspid teeth document three distinct squamate morphotypes at TAR-21 (morph 1: corrugated enamel; Fig. 4M') and TAR-01 (morph 2: high-crowned and sharp-edged [Fig. 5P]; morph 3: bulbous crown), probably assignable to scincomorphan lizards (teiids?). Neither snake remains nor lacertilian osteoderms were unearthed in the concerned localities.

\subsubsection{Chelonians (turtles and tortoises)}

Chelonian remains occur throughout the section (TAR-20, TAR-21, TAR-22, and TAR-01). The concerned fossil specimens consist of isolated smooth-surfaced scutes, referable to unidentified pelomedusoid pleurodiran turtles, and documenting a wide size range. In particular, they are substantially large sized at TAR-22.

\subsubsection{Crocodylomorphs (crocodylians and their stem relatives)} At Shapaja, crocodylomorphs are documented from most localities by basically isolated, smallsized teeth. The Shapaja communities include two (TAR-74, TAR-72, and TAR-22) up to four (TAR21), and even five co-occurring crocodylomorph taxa (TAR-01). Sebecosuchians (extinct terrestrial crocs) occur in TAR-74, TAR-72, TAR-22, and TAR-01 (Fig. 4N'$\left.\mathrm{O}^{\prime}\right)$. Teeth, easily recognizable thanks to their triangular profile, almond-shaped cross section and serrated edges, are referred to as Sebecidae indet. (sensu Pol \& Powell, 2011). The fragmentary state of the available sample and the sparse Paleogene fossil record of sebecosuchians in tropicalequatorial areas of South America discards to refine further their taxonomic assignment or to consider the co-occurrence of several taxa.

Elongated teeth with fluted enamel, typical of longirostrine fish-eating crocodylians are recognized throughout the section (from TAR-74 up to TAR-01). They are either assignable to unidentified crocodyloids or gavialoids (Fig. 4P') in all localities. Only at TAR-20 a large tooth with a clear Sshaped profile can be referred to as a gryposuchine gavialoid. The record of caimanine teeth far exceeds that of other crocodylomorph components at Shapaja (TAR-20 to TAR-01; Fig. 4Q'-S', 5Q-V). A complete skull (under study by RSG) and an osteoderm referable to this group were also recovered at TAR-20 and TAR-21, respectively. Teeth may document several morphs related to caimans, including globular, blunt with a short crown, leafshaped (MUSM 3980; Fig. 4R'-S') and conical with strongly-fluted enamel morphs, aside from the more "generalized" caiman dental shapes (Fig. 5Q-V; for a review, see Salas-Gismondi et al., 2015). 
Dipnoi (lungfish)

Dipnoan dental plates of a single morph and dentine/bone structure, but of two distinct sizes, were uncovered in localities of the Shapaja section. Small ones occur throughout the considered section (from TAR-74 to TAR-01). They are mostly documented through tiny fragments (Fig. 3), sometimes as conspicuous elements of the ichthyofaunal community (up to 21 and 24 specimens at TAR-21 and TAR-01, respectively; Fig. 5W). The largest ones only occur in late Eocene localities (TAR-20, TAR-72, TAR-21; Fig. 4T'), which is not primarily linked to stream energy, as a similar grain size is recorded at TAR-22 and TAR-73 (earliest Oligocene). They are far smaller than tooth plates of Lepidosiren recorded in Miocene deposits of Brazil, Colombia, and Peru (Lundberg, 1997; Toledo \& Bertini, 2005). All these remains are referred to as Lepidosirenidae indet.

\section{Actinopterygians (ray-finned fish)}

Characiforms (characins and kin) dominate the actinopterygian record (see SI), with a constant composition throughout the Shapaja section (from TAR-74 to TAR-01). Most if not all localities have yielded isolated teeth referable to serrasalmids (pacu, cf. Colossoma sp.; 2,230 specimens at TAR-01; Fig. 5X), anostomids (cf. Leporinus sp., incisor-like and hexacuspid [rare; Fig. 4U']; Leporinus sp., incisor-like and paddle-shaped teeth [629 specimens at TAR-01; Fig. 5A'-B'], and cynodontids (cf. Hydrolycus sp., monocuspid, sharp and dagger-like teeth; 359 specimens at TAR01; Fig. 5C'). Unidentified hook-like, pad-like, and acuminated unicuspid pharyngeal teeth add to the characiform record. TAR-01 yielded three millimetric razor-sharp bicuspid teeth with an interlock furrow, unquestionably referable to as a crown piranha, and closely resembling the $4^{\text {th }}$ or $5^{\text {th }}$ tooth of the dentary of Serrasalmus (cf. Serrasalmus sp., Fig. 5Y-Z; Shellis \& Berkovitz, 1976). In contrast, siluriforms (catfish) are mostly documented by pectoral and/or dorsal spines at TAR20, TAR-21, and TAR-01 (Siluriformes indet.). A small muffle-shaped tooth from TAR-21 and a small spine with a typical punctuated ornamentation from TAR-01 are assigned to an unidentified loricariid (armored catfish; Loricariidae indet.). The tooth has a small accessory cusp at the tip of the crown (Fig. $4 \mathrm{~V}^{\prime}$ ), contrary to the loricariid teeth from Miocene deposits of Contamana (Antoine et al., 2016). A cranial fragment of a large-sized goliath catfish recovered at TAR-22 is recognizable thanks to the ornamented external aspect, with thick ridges and elongated sulci (Fig. $4 \mathrm{~W}^{\prime}$ ). It is referred to as a pimelodid, cf. Phractocephalus sp. (for comparison, see Lundberg \& Aguilera, 2003; Aguilera et al., 2008).

\section{Selachians (sharks, skates, and rays)}

Both the oldest (TAR-74) and the youngest Shapaja localities (TAR-73 and TAR-01) have not yielded a single selachian specimen, whereas all interbedded localities gather one to four co-occurring selachian species. Myliobatiforms are fully dominant over pristiforms (see SI). The most conspicuous elements by far are freshwater stingrays (Potamotrygonidae), with a new species of Potamotrygon documented at TAR-20, TAR-21, and TAR-22 (one to 40 teeth per locality; Fig. 4Z'$\mathrm{A}^{\prime \prime}$ ), Potamotrygon canaanorum at TAR-13 (previously restricted to upper Oligocene-upper Miocene deposits from Contamana area; Chabain et al., 2017), and a representative of Paratrygon (Paratrygon sp.) at TAR-21 and TAR-22 (Fig. 4X'-Y'). To our knowledge, these are the first fossil occurrences of this Recent monotypic genus. Myliobatids occur at TAR-20, TAR-72, and TAR-13 (with a neonate tooth in each locality), and TAR-21 (20 teeth of Myliobatis sp. [Fig. 4E"-F"] and a tooth assigned to the bat ray ?Rhinoptera). Some Myliobatis specimens are particularly large (30 mm-long) at TAR-21, whereas unusually small batoid specimens in TAR-20, TAR-72, and TAR-13 are cautiously interpreted as documenting neonate/young specimens of bat rays (?Myliobatis; Fig. $4 C^{\prime \prime}-D^{\prime \prime}$ ). In addition, a single oral tooth of the sawfish Pristis sp. was recognized at TAR-22 (Fig. $\left.4 \mathrm{~B}^{\prime \prime}\right)$. To sum up, the Shapaja selachian sample likely attests to the presence of a single and 
consistent community between TAR-20 and TAR-22, with brackish/coastal plain affinities, as indicated by bat rays and Pristis.

\section{Discussion}

\subsection{Age}

Here we performed, for the first time, chemostratigraphical investigation using carbon isotopes on dispersed organic matter $\left(\delta^{13} \mathrm{C}_{\text {org }}\right)$ and pedogenic nodules $\left(\delta^{13} \mathrm{C}_{\text {nod }}\right)$ at Shapaja (Western and Eastern sections), in order to i) provide a stratigraphic framework of the upper part of the Pozo Fm. in the Tarapoto area (Peruvian Amazonia), ii) refine the position of nine fossil-bearing levels in this stratigraphic framework. Unravelling the age of fossil-bearing levels in terrestrial to proximal marine sections is challenging mainly due to the lack of marine biostratigraphical reference fossils. Moreover, usage of certain terms has changed through time regarding the Eocene/Oligocene boundary (EOB; Premoli-Silva \& Jenkins, 1993; Hutchison et al., 2020). In common practice, the EOB is linked to the Oi-1 event, based on $\delta^{18}$ O perturbations (Van Mourik and Brinkhuis, 2005). The late Eocene-early Oligocene interval comprised several isotopic events initially defined by Miller et al. (1991). The oldest of these events are major $\delta^{18} \mathrm{O}$ and $\delta^{13} \mathrm{C}$ positive shifts, starting in the latest Eocene and ending in the earliest Oligocene (e.g., Coxall et al., 2005; Katz et al., 2008; Lear et al., 2008; Vandenberghe et al., 2021; Fig. 2). This isotopic event, called Eocene-Oligocene (climate) transition (EOT), lasting $500 \mathrm{kyr}$ (Coxall and Pearson, 2007), then encompasses the Eocene-Oligocene boundary. The EOB occurs approximately two thirds of the way through the EOT (Hutchison et al., 2020). Using a high-resolution carbon isotope study of the ODP site 1218, Erhardt et al. (2013) showed that the EOT positive shift is followed by two positive $\delta^{13} \mathrm{C}$ and $\delta^{18} \mathrm{O}$ excursions called $\mathrm{Oi}-1$ and $\mathrm{Oi}-1 \mathrm{a}$, both earliest Oligocene in age. This isotopic pattern was also observed by Zhifei et al. (2004) in ODP Leg 208 Site 1262, 1265 and 522. These trends are followed by another positive excursion (Oi-1b), clearly showing lighter maximal values than Oi-1 and Oi-1a excursions. While diagenesis increasingly alters the oxygen-isotope signature of sediments, Cisotope geochemistry is less influenced by diagenesis (Weissert et al., 2008). Oxygen isotopes $\left(\delta^{18} \mathrm{O}\right)$ on organic matter do not provide primary signals and are therefore not useful for stratigraphy. Conversely, variations in terrestrial organic carbon-isotope composition $\left(\delta^{13} C_{o r g}\right)$ allow for using C-isotope stratigraphy as tool for correlating marine and terrestrial records, as demonstrated in a wide array of sections and time intervals (e.g. Gröcke et al., 1999). These variations have been satisfactorily used for allocating the position of Paleogene fossil-bearing levels in terrestrial sections (e.g. Yans et al., 2014a,b; Noiret et al., 2016), including the EOB and around (Benammi et al., 2019).

The Shapaja section was previously assigned an early Oligocene age (Klaus et al., 2017; Boivin et al., 2018, 2019a, 2019b), then a late Eocene-early Oligocene age range, on the basis of paleontological content and lithological correlations (Assemat et al., 2019). In the Western section of Shapaja, our new isotopic data on both organics $\left(\delta^{13} \mathrm{C}_{\text {org }}\right)$ and pedogenic nodules $\left(\delta^{13} C_{\text {nod }}\right)$ clearly show (Fig. 2): i) a positive shift attributed to the EOT event, ii) followed by quite positive values considered as $\mathrm{Oi}-1$, iii) overlaid by a positive excursion interpreted as $\mathrm{Oi}-1$ a. These isotope trends perfectly match those observed at the global cooling of the Eocene-Oligocene transition described above (Ehrardt et al., 2013). During Paleogene to Miocene times, similar C-isotope patterns, showing two successive high-amplitude positive $\delta^{13} \mathrm{C}$ excursions, are only recorded after the Mid-Eocene Climatic Optimum (MECO, Bartonian) and around the Mid-Miocene Climatic Optimum (MMCO, Langhian; Zachos et al., 2001; Luciani et al., 2010; Vandenberghe et al., 2012). As mentioned above, the MECO and MMCO time intervals are widely at odds with the inferred biostratigraphic age range of Shapaja localities studied here. Moreover, middle Miocene fossils have been collected $\sim 1,800 \mathrm{~m}$ above TAR-01 (at TAR-31 locality; Marivaux et al., 2020) whereas 
late Middle Eocene rodents were recognized at TAR-67, i.e., $280 \mathrm{~m}$ below the lowermost locality (TAR-74; Fig. 1). The uppermost positive peak at Shapaja $(-6.9 \%$ at $113.5 \mathrm{~m})$ may be interpreted as $\mathrm{Oi}-1 \mathrm{~b}$ but this remains tentative since i) this peak is based on a single point and ii) $\delta^{13} \mathrm{C}_{\text {org }}$ does not show the same trend for this sample. The main part of the Eastern section shows a negative trend, interpreted as global negative trend observed below the EOT (Fig. 2), which further matches local lithological sequences and taxonomic affinities of the concerned paleocommunities. In Shapaja, the C-isotope values on organics and pedogenic nodules are globally consistent, showing similar trends (Fig. 2). However, two minor discrepancies are observed in the following intervals: i) hypothetical base of the EOT located in the $\delta^{13} \mathrm{C}_{\text {org }}$ curve $\sim 20 \mathrm{~m}$ above its location in the $\delta^{13} C_{\text {nod }}$ curve, and ii) negative trend of the Oi-1a excursion, well-marked in the $\delta^{13} C_{\text {nod }}$ curve (from $-5.8 \%$ at $81.2 \mathrm{~m}$ to $-11.3 \%$ at $98.3 \mathrm{~m}$ ) and less marked in the $\delta^{13} \mathrm{C}_{\text {org }}$ curve. These local inconsistencies may be explained by the poor carbon content of organics (usually $<0.05 \%$ ) in all studied samples. In Shapaja, organic matter most probably experienced intense recent oxidation/weathering, leading to potential biases in the resulting $\delta^{13} \mathrm{C}_{\text {org }}$ values/trends. We therefore consider the data on pedogenic nodules as more robust (meteoric water-sourced), allowing us to use the $\delta^{13} C_{\text {nod }}$ values as the best primary signals where data on both the studied materials (organics vs nodules) are not consistent.

Our data in the Western section suggest that the EOT is observed between 53 and $59 \mathrm{~m}$ using $\delta^{13} \mathrm{C}_{\text {org }}$ data, and between 32 and $59 \mathrm{~m}$, using $\delta^{13} \mathrm{C}_{\text {nod }}$ data. Thus, the EOB is located somewhere in this latter interval (Fig. 6). It is not possible, however, to refine the location of the EOB, at our current stage of knowledge. Based on these new chemostratigraphical data, we conclude that i) TAR-20 and TAR-72 (and TAR-74, even if this underlying level was not sampled in our study) are late Eocene in age, ii) TAR-21 is located at the earliest EOT (i.e., most probably latest Eocene in age), iii) TAR-21sup is within the EOT (latest Eocene? - earliest Oligocene?), and iv) TAR-22, TAR13, TAR-73, and TAR-01 are early Oligocene in age.

Among metatherians, most new records of palaeothentids and abderitids at Shapaja are consistent with previously-estimated divergence times (i.e., earliest Oligocene; Abello et al., 2018). However, the presence of palaeothentines by the EOT at Shapaja implies an unexpected ghost lineage of the group, and as such, a much earlier divergence, not only of the palaeothentids and abderitids, but also of the major palaeothentid lineages (i.e. Palaeothentinae and Acdestinae). Further studies (in progress) will allow to test the current taxonomic assignations and to refine diversification timings of non-Pichipilidae Palaeothentoidea.

\subsection{Environment}

The abundance of pedogenic nodules (calcretes) throughout the latest Eocene-early Oligocene interval points to contrasted seasonal rainfall and water-table oscillation. The poor palynomorph recovery at TAR-72 is compatible with understory vegetation in a tropical rainforest (Fungi monocellate and fern spores) and with seasonal water-table fluctuation.

Quantitative paleoclimatic inferences were not performed due to the limited number of leaf and seed fossil material that could be collected in the field. The Shapaja record, however, consists mostly of nanophyll leaflets of compound leaves or microphyll leaves. In addition, most of the fossil leaves recovered came from the early Oligocene section (i.e., TAR-01), which could indicate that the forests at this time likely adapted to longer periods of drought (e.g., strong seasonal precipitation pattern) by becoming deciduous and reducing the leaf lamina (see Peppe et al., 2011). Nevertheless, larger collections are necessary to confirm this hypothesis. Interestingly, recent studies documenting macrofloras throughout the late Eocene to early Oligocene from Neotropical localities also provide evidence to support an increment in seasonal conditions in this region (Calvillo-Canadell and Cevallos-Ferriz, 2005; Woodcock et al., 2017; Martínez et al., this issue), a pattern that has been previously proposed for northern high-latitude localities (Eldrett et 
al., 2009). Most of the taxonomically identified fossil seeds came from the latest Eocene locality (TAR-21), which includes at least two taxa of Passifloroideae (passion fruit subfamily) and one taxon of the Araceae (cf. Monstera). These plants are common vines or epiphytes in extant tropical rainforests in the region. The presence of these plants in the latest part of the Eocene also coincides with the occurrence of primates, indicative of tropical rainforest environment (Fig 4V$\left.C^{\prime}\right)$. The persistence of vine/epiphytic plants suggests the presence of high-canopy trees in this part of the section near the vicinity of streams (TAR-74 to TAR-73) and ponds (TAR-01) throughout the section. Seeds of Nymphaceae (TAR-73) and cf. Elatine (Elatinaceae; TAR-74 and TAR-01; Fig. 3I), a common cosmopolitan plant of aquatic environments (e.g., ponds, freshwater lakes), also indicate the presence of freshwater settings. Moreover, the oldest and youngest localities (TAR-74 and TAR-73 + TAR-01, respectively) testify to the presence of obligate freshwater settings, as revealed by the mollusk, decapod, and fish communities. Conversely, a marine/brackish influence can be hypothesized in the middle part of the section (between TAR-20 and TAR-22) thanks to the conspicuous presence of myliobatid and pristid selachians (bat rays and sawfish, respectively). These taxa co-occur with a freshwater ichthyofauna dominated by characiform actinopterygians and dipnoans, thus pointing to an estuarine environment. The presence of neonate/young batoid specimens at TAR-20, TAR-13, and TAR-72 might further support brackish conditions for the concerned interval, as many Myliobatis females enter estuaries and coastal plains to give birth today (Mianzan et al., 2001). Accordingly, we can hypothesize that the concerned settings were close to such protected environments playing a nursery role for bat rays (even if the occurrence of a minute euryhaline/freshwater myliobatid species of unknown affinities cannot be fully discarded). In the uppermost levels of the section (TAR-73 and TAR-01), the fish community characterizes again a freshwater environment without any marine influence (potamotrygonid selachians, dipnoans, and characiform actinopterygians). Nodule-rich blue clays of TAR-01 may have deposited in an oxbow lake, which would further explain the presence of piranhas (see CTA32 near Contamana; Antoine et al., 2016).

\subsection{Community turnovers}

In this section, we provide a short overview of the most prominent taxonomic groups for which changes have been recognized in terms of community composition over the studied section. The faunal components of the different localities were informally grouped into three assemblages based on taxonomic composition of relevant groups. Assemblages 1 and 3 refer to the late Eocene (TAR-74) and early Oligocene (TAR-01) metatherian, rodent, and fish assemblies, respectively, while Assemblage 2 refers to the latest Eocene-earliest Oligocene transitional taxonomic composition (TAR-20, TAR-72, TAR-21, TAR-22, and TAR-73).

Charophyte and plant remains (leaves, silicified wood, and seeds) are documented throughout the complete studied section. Changes in the diversity of the leaf macroflora along the section are hard to evaluate as most of the material collected came from only one Oligocene locality (TAR-01). Nevertheless, we found two leaf morphotypes (PZ1 and PZ3, shared between TAR-21sup (EOT) and TAR-01), and also one seed taxon, cf. Elatine (shared between TAR-74 and TAR-01), implying that these plants persisted to the EOT and were tolerant of the new climatic conditions of the early Oligocene. Although additional plant fossil material will be required to fully reconstruct the forest types of the Shapaja section, our preliminary data suggests the presence of multistratified rainforests during the latest part of the Eocene (TAR-21) and more open, deciduous forests in the earliest Oligocene (TAR-21sup to TAR-01). 


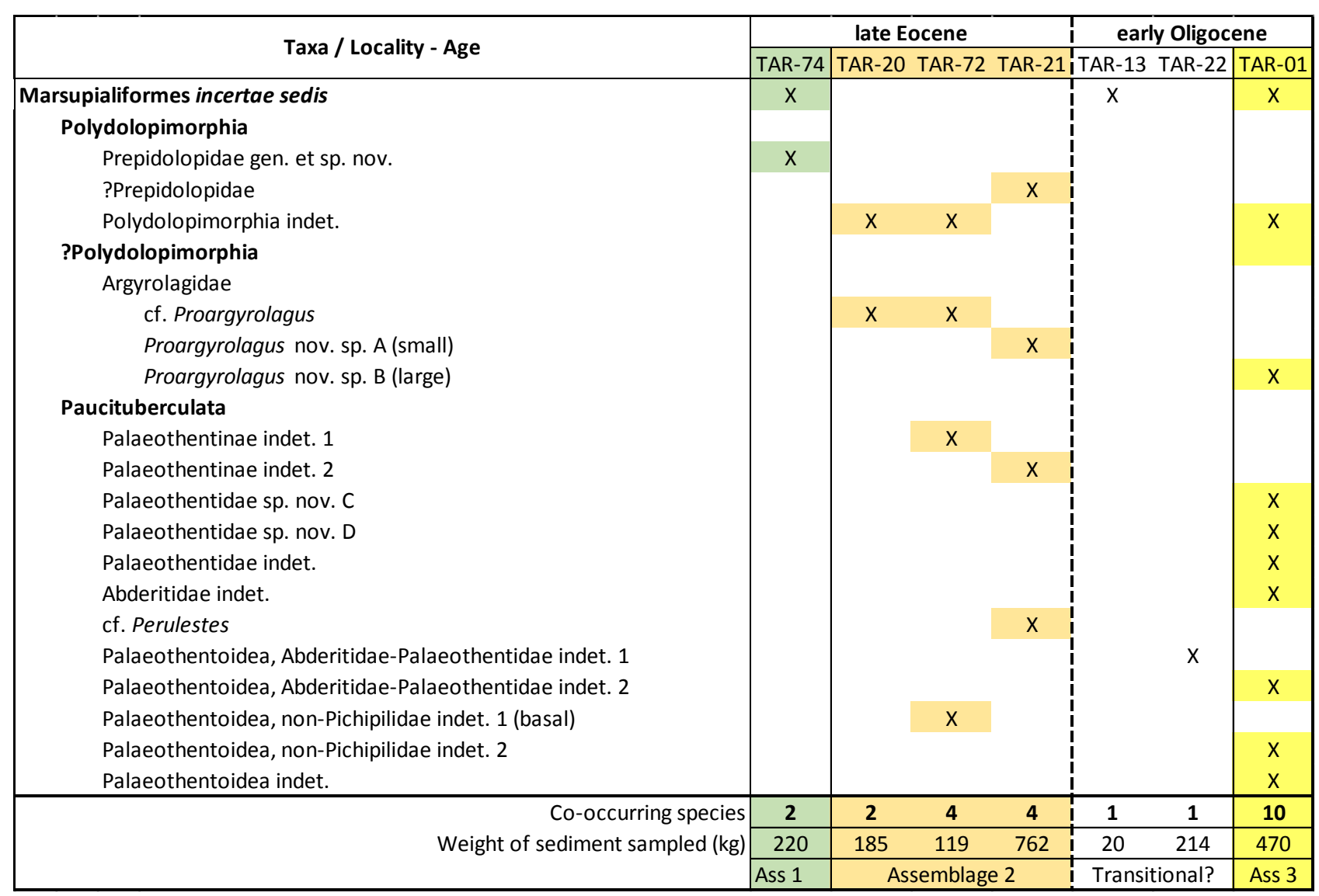

Table 2. Taxonomic composition of metatherian communities from the late Eocene-early Oligocene Shapaja section, San Martín, Peruvian Amazonia, suggesting the presence of two successive turnovers (Assemblages 1-3), as for rodents (Table 3) and fish assemblies (Table 4, Fig. 6). Ass, Assemblage.

As for mammals, only metatherians and rodents are sufficiently documented in terms of specimen numbers and taxonomic richness to provide evidence related to faunal turnovers (Tables 2-4). Among metatherians, the Assemblage 1 (TAR-74, late Eocene) yields a new prepidolopid and an unidentified marsupialiaform, but neither argyrolagids nor palaeothentoids, which fully dominate latest Eocene assemblages (from TAR-20 to TAR-21; Assemblage 2). Another obvious turnover is observed between TAR-21 and TAR-01 (Assemblages 2 vs. 3: no species in common). Indeed, latest Eocene localities (Assemblage 2) are fully dominated by small argyrolagids, very abundant in TAR21 and co-occurring with another possible prepidolopid and some early palaeothentoids. By the early Oligocene, however, argyrolagids are much less conspicuous while there is a profusion of derived non-Pichipilidae palaeothentoids, with the presence of new taxa among Palaeothentidae and Abderitidae (TAR-01: Assemblage 3). Unfortunately, the timing of this turnover cannot be refined, due to the lack of marsupial remains in interbedded localities (TAR-13, TAR-22, and TAR73; Table 2). Even though a sampling bias cannot be fully discarded, the differences between Shapaja Assemblages 2 and 3 might well illustrate a real change in taxonomic composition and diversity. A sharp decline of metatherian diversity by the EOT has already been observed as part of the Patagonian hinge ("Bisagra patagónica"; Goin et al., 2010, 2016): Patagonian faunas reveal the EOT as a major ecologically-induced turnover in the history of Metatheria, with the disappearance of some lineages and the diversification of other ones (Goin et al., 2016). With respect to other Eocene-Oligocene South American metatherian faunas, Shapaja communities are fully distinct from the Tinguiririca fauna, Chile (Flynn et al., 2003) and very dissimilar to those of Argentinean Patagonia (La Cancha and La Cantera) and Southeastern Brazil (Guabirotuba), except for the presence of basal NPPs and argyrolagoids (Goin et al., 2010; Sedor et al., 2017). Strikingly, except 
for yielding a prepidolopid and basal NPPs (Perulestes and Sasawatsu), the Santa Rosa fauna does not have strong affinities with Shapaja metatherian assemblages: sparassodontans, microbiotherians, and other Polydolopimorphia (e.g., Wamradolops and Rosendolops) do not occur at Shapaja; Argyrolagidae, Palaeothentidae (including Palaeothentinae), and Abderitidae have not been found at Santa Rosa. Shapaja and coeval mid- and low-latitude metatherian paleocommunities need to be thoroughly revised and compared with their higher latitude counterparts, in order to unravel their evolutionary dynamics at the South American scale.

\begin{tabular}{|c|c|c|c|c|c|c|c|}
\hline \multirow{2}{*}{ Taxa / Locality - Age } & \multicolumn{4}{|c|}{ late Eocene } & \multicolumn{3}{|c|}{ early Oligocene } \\
\hline & TAR-74 & TAR-20 & TAR-72 & TAR-21i & TAR-13 & TAR-22 & TAR-01 \\
\hline \multicolumn{8}{|l|}{ Caviomorpha } \\
\hline \multicolumn{8}{|l|}{ Stem Caviomorpha } \\
\hline Pozomys sp. nov. & $\mathrm{x}$ & & & & & & \\
\hline Tarapotomys subandinus & & $\mathrm{x}$ & $\mathrm{x}$ & $\mathrm{x}$ & & $\mathrm{x}$ & \\
\hline Tarapotomys mayoensis & & & & & & & $\mathrm{x}$ \\
\hline aff. Tarapotomys sp. & & & & $\mathrm{x}$ & & & \\
\hline Caviomorpha gen. et sp. nov. & & $\mathrm{x}$ & & $x$ & $\mathrm{x}$ & & \\
\hline Shapajamys labocensis & & & & & & & $\mathrm{X}$ \\
\hline \multicolumn{8}{|l|}{ Incertae sedis } \\
\hline Caviomorpha gen. et sp. indet. 1 & & $\mathrm{x}$ & & $\mathrm{x}$ & & & \\
\hline Caviomorpha gen. et sp. indet. 2 & & & & & & $x$ & \\
\hline Caviomorpha gen. et sp. indet. 3 & & & & & & $x$ & \\
\hline Caviomorpha gen. et sp. indet. 4 & $\mathrm{x}$ & & & & & & \\
\hline Caviomorpha gen. et sp. indet. 5 & & & & $x$ & & & \\
\hline \multicolumn{8}{|l|}{ Erethicavioi } \\
\hline \multicolumn{8}{|l|}{ Erethizontoidea } \\
\hline Eopululo cf. wigmorei & $\mathrm{x}$ & & & & & & \\
\hline Kichkasteiromys raimondii & & & & $x$ & & & \\
\hline \multicolumn{8}{|l|}{ Octochinchilloi } \\
\hline Mayomys confluens & & & & & & & $x$ \\
\hline \multicolumn{8}{|l|}{ Octodontoidea } \\
\hline Adelphomyidae gen. et sp. indet. & & & & & $x$ & & \\
\hline Selvamys paulus & & & & & | & $\mathrm{x}$ & \\
\hline \multicolumn{8}{|l|}{ Chinchilloidea } \\
\hline Eoincamys valverdei & & $x$ & $\mathrm{x}$ & $x$ & $x$ & $x$ & \\
\hline Eoincamys parvus & & $x$ & & $x$ & & $x$ & \\
\hline Eoincamys cf. pascuali & & & & & & & $\mathrm{x}$ \\
\hline ?Eoincamys sp. 1 (TAR-74) & $\mathrm{x}$ & & & & & & \\
\hline ?Eoincamys sp. 2 (TAR-13) & & & & & $x$ & & \\
\hline Chinchilloidea gen. et sp. indet. & & & & & & & $\mathrm{x}$ \\
\hline \multirow{3}{*}{$\begin{array}{r}\text { Co-occurring species } \\
\text { Weight of sediment sampled }(\mathrm{kg})\end{array}$} & 4 & 5 & 2 & 8 & 4 & 6 & 5 \\
\hline & 220 & 185 & 119 & 762 & 20 & 214 & 470 \\
\hline & Ass 1 & \multicolumn{5}{|c|}{ Assemblage 2} & Ass 3 \\
\hline
\end{tabular}

Table 3. Taxonomic composition of caviomorph rodent communities from the late Eocene-early Oligocene Shapaja section, San Martín, Peruvian Amazonia, suggesting the presence of two successive turnovers (Assemblages 1-3), as for metatherians (Table 2) and fish assemblies (Table 4, Fig. 6). Ass, Assemblage. 
According to our results, three distinct rodent communities are recognized in the studied Shapaja section (Assemblages 1-3; Table 3). The Assemblage 1 and 3 are late Eocene and early Oligocene in age, respectively, whilst the Assemblage 2 is well documented in both latest Eocene and earliest Oligocene localities. Four species of this Assemblage 2 survive the EOT locally (Tarapotomys subandinus, Caviomorpha gen. et sp. nov., Eoincamys valverdei, and E. parvus). More generally, chinchilloids and erethizontoids first occur prior to the EOT, whereas octodontoids (as represented by Adelphomyidae indet. gen. et sp. at TAR-13 and Selvamys at TAR-22) appear after the EOT, at least locally. The most prominent turnover occurs between TAR-22 (Assemblage 2) and TAR-01 (Assemblage 3), with species replacements among Tarapotomys ( $T$. subandinus versus $T$. mayoensis) and Eoincamys (E. valverdei + E. parvus versus E. cf. pascuali), and the first appearance of both Shapajamys and of Mayomys at TAR-01. As illustrated by distinct depositional settings, this turnover likely concurs with environmental changes locally, potentially related to the EOT. Nevertheless, the corresponding turnover does not coincide temporally with this event but occurs somewhat later (by Oi-1a times; Fig. 2, 6). Strikingly, all stratigraphically-constrained Shapaja rodent assemblages (1-3), spanning the late Eocene-early Oligocene time interval (ca. 36-32.5 $\mathrm{Ma})$, are equally homotaxic with the Santa Rosa rodent fauna, notably in sharing a stem caviomorph (Pozomys; TAR-74), erethizontoids (from TAR-74 upward), chinchilloids (with a strong domination of Eoincamys at TAR-20 and younger localities), and adelphomyine octodontoids (at TAR-13; Boivin et al., 2018, 2019a, 2019b). This raises questions about Santa Rosa i) consisting of several successive fossil-yielding levels of distinct ages or ii) being a time-averaged level with reworked specimens, as further suggested by its extreme rodent specific richness (17 co-occurring species; Arnal et al., 2020), recalling that of upper Oligocene Salla Beds, Bolivia (multiple fossilbearing levels, 29-25 Ma; e.g., Pérez et al., 2019).

So far, no primate has been recorded in the early Oligocene TAR-01 locality, which has been sampled as extensively as TAR-21 and has yielded a specimen-rich rodent fauna (868 specimens). Most tiny primates are dependent on dense forest habitats, and can be highly sensitive to environmental changes. Although a taphonomic bias cannot be ruled out for explaining this contrast between TAR-21 and the well-sampled overlying early Oligocene localities (i.e., TAR-22 and TAR-01), the apparent rarefaction of primates in post-EOT deposits could also be linked to paleoenvironmental changes, at least locally, thereby corresponding to the onset of drier/open terrestrial environments by the EOT or afterwards.

Even if it is likely to predate it, the bispecific primate community at TAR-21 strongly recalls that of Santa Rosa (Bond et al., 2015; Seiffert et al., 2020). Conversely, poorly-documented Shapaja ungulate assemblies seem to be highly distinct, at least for northern South America. 


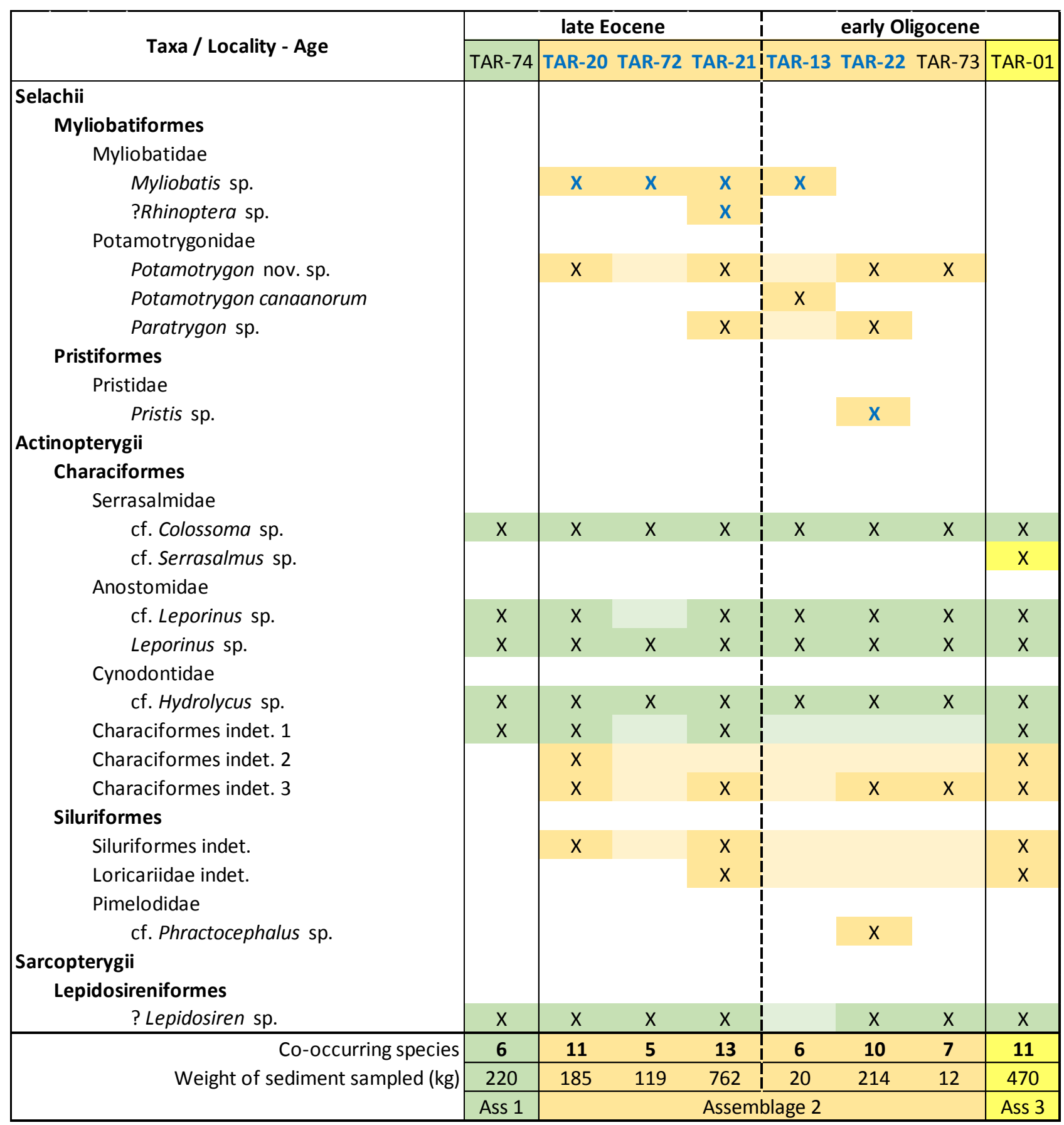

Table 4. Taxonomic composition of fish communities from the late Eocene-early Oligocene Shapaja section, San Martín, Peruvian Amazonia, suggesting a turnover pattern similar to that of metatherian and rodent paleocommunities (see Tables 2-3, Fig. 6). Blue-typed occurrences and locality names refer to the marine affinities of Assemblage 2 (mixohaline coastal plain), as hypothesized by the presence of myliobatiform and pristiform selachians. Ass, Assemblage.

The Shapaja fish faunas are strongly reminiscent of the modern Amazonian lowland ichthyofauna, with characiform and siluriform actinopterygians, potamotrygonid selachians, and dipnoans (Brito and Deynat, 2004). They also recall the middle Eocene-late Miocene freshwater-dominated fish communities from Contamana (Adnet et al., 2014; Antoine et al., 2016; Chabain et al., 2017). In more detail, the Shapaja fish communities have distinctive features (Table 4), such as the conspicuous presence of a new species of Potamotrygon (in TAR-20, TAR-21, and TAR-22), the first fossil occurrence of the discus ray Paratrygon (TAR-21 and TAR-22), and the earliest occurrence of loricariid siluriforms (TAR-21), of Potamotrygon canaanorum (TAR-13; previously restricted to 
upper Oligocene settings; Chabain et al., 2017), and of piranhas closely allied to Serrasalmus (TAR01; previously recorded from upper Oligocene settings onward; Antoine et al., 2016). TAR-74 and TAR-01 did not yield any selachian specimens, in spite of having been extensively sampled (Table 4; see SI). Despite the large amount of sediment sampled (220 kg), the fish community at TAR-74 only consists of characiforms and lepidosirenid dipnoans, typical of running-water settings, and consistent with those of overlying localities (TAR-20 to TAR-73). However, the localities TAR-20 to TAR-22 yielded selachians of marine/brackish affinities, such as Myliobatis, Rhinoptera, and/or Pristis. The presence of Myliobatis neonates (at TAR-20, TAR-72, and TAR-13) may further point to a mixohaline coastal plain environment (bat ray nurseries). In contrast, the distinctiveness of TAR01 in terms of ichthyofaunal content, without any selachians and further illustrated by the presence of piranhas, may be related to the depositional setting (oxbow lake), contrasting with that of all underlying localities, although the role of other EOT-related drivers cannot be discarded (Table 4). In other words, the discrepancies between Shapaja fish Assemblages 1-3 appear to be mainly related to environmental conditions, with a strict freshwater setting (TAR-74: Assemblage 1), a transgressive lag (brackish interval from TAR-20 to TAR-22: Assemblage 2), and a subsequent regression (TAR-01: Assemblage 3). TAR-73 may correspond to a transitional phase between the Assemblages 2 and 3 (no marine component, but a potamotrygonid).

\subsection{Regional and/or global drivers}

Assessing which drivers have provoked past biotic changes is quite challenging, especially in areas as widely under-investigated paleontologically as tropical-equatorial regions of South America. In the Shapaja section recording and bracketing the EOT, we will nonetheless try to disentangle the potential roles of main regional and global drivers (i.e., vertical movements vs. climatic and sea-level changes, respectively), likely to explain the biotic turnovers observed during the late Eocene-earliest Oligocene interval.

From a tectono-sedimentary perspective, the Shapaja area is located in the Sub-Andean Zone today. Recent regional syntheses for the Huallaga and Bagua basins in the northern Central Andes consistently state that the concerned area only experienced Andean thrust-related deformation much later, i.e., from late Miocene times onward (Hermoza et al., 2005; Roddaz et al., 2010; Eude et al., 2015; Moreno et al., 2020). During the late Eocene-Oligocene interval, this region was steadily part of the foredeep depozone of the foreland basin. This time period coincides with the onset of a tectonic loading stage, leading locally to flexural subsidence (Roddaz et al., 2010). Such downward settling likely forced the late Eocene shift from freshwater to brackish/marine-influenced depositional environments, as recorded locally between TAR-74 and TAR-20 and further illustrated by the first ichthyofaunal turnover (Fig. 6: Assemblage 1 vs. Assemblage 2). In addition, this shift occurred during a time period with no noticeable global sealevel change (Fig. 6; Miller et al., 2020). Thereby, the concerned late Eocene biotic changes might 

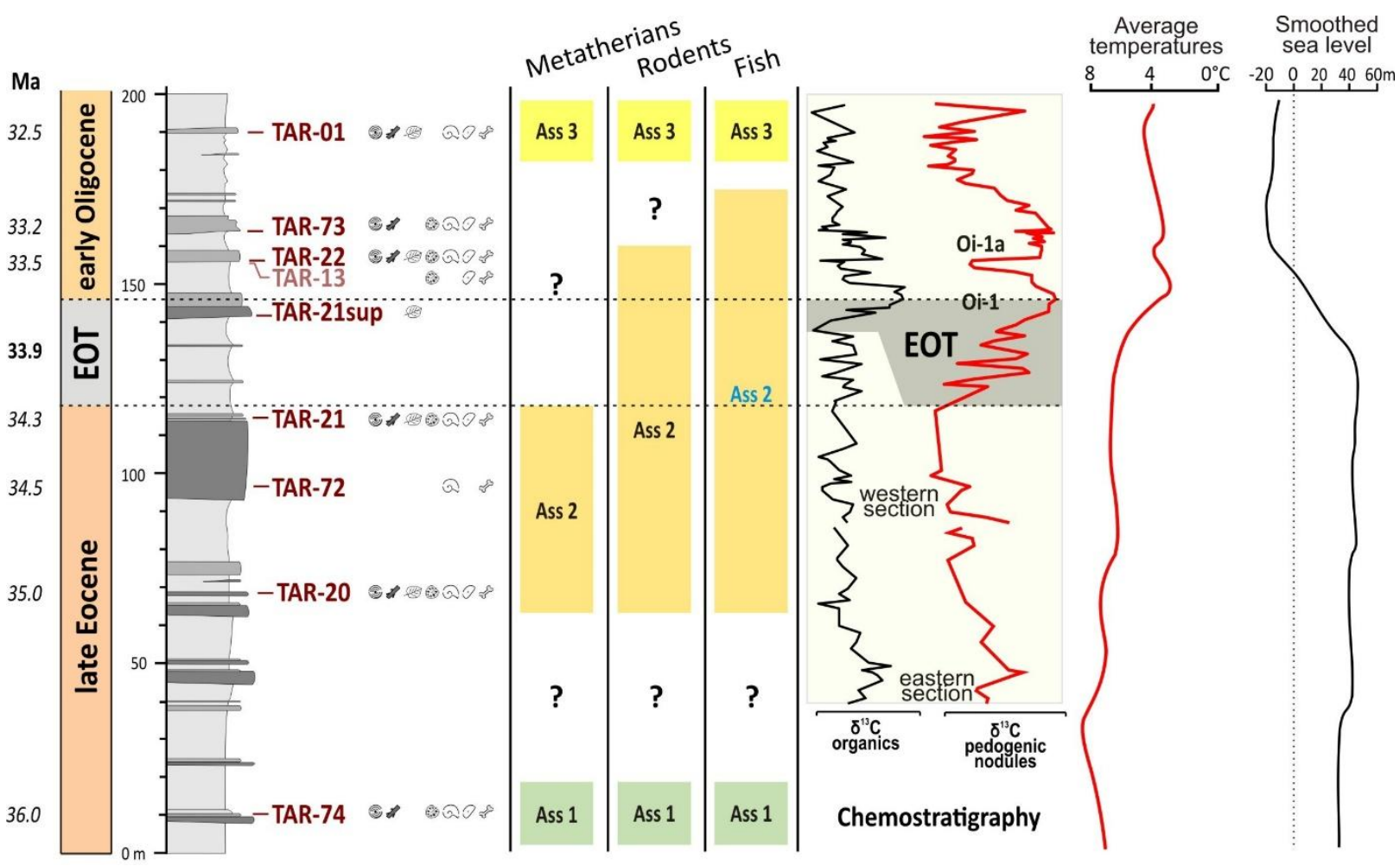

Fig. 6. Synthetic chrono-biostratigraphical chart of late Eocene-early Oligocene paleocommunities from Shapaja, San Martín, Peruvian Amazonia. Timeframe based on Vandenberghe et al. (2012) and current chemostratigraphical analyses. Ages in italics are approximate and tentative. Assemblages 1-3 derive from the present work, based on metatherian, rodent, and fish assemblages (selachians + actinopterygians) (see Tables 2-4). Blue-typed fish component refers to the marine affinities of Assemblage 2 (mixohaline coastal plain). Paleotemperature curve (Westerhold et al., 2020) and smoothed sea level curve (Miller et al., 2020) are adapted to match the timeframe of the section.

In contrast, the time interval spanning the EOT and the earliest Oligocene records unstable and deteriorating global conditions: a drastic cooling led to a ca. $80 \mathrm{~m}$ drop in sea level between ca. 34 and 33.2 Ma (Fig. 6), provoked a sustained drop in precipitation, and increased seasonality, with a worldwide onset of drier climatic regimes (Hutchinson et al., 2018; Miller et al., 2020; Westerhold et al., 2020). Both the abundance of pedogenic nodules in the concerned interval of the Shapaja section and the concurrent shift from multistratified rainforest to more open deciduous forest consistently point to the strengthening of seasonal contrast, especially regarding rainfall (see previous sections). This global event temporally coincides with the decay of the Assemblage 2, as perceived on metatherians and rodents (Fig. 6). The apparently-delayed response of the ichthyofaunal community (turnover starting ca. 33-32.5 Ma) with respect to that of terrestrial components (plants and mammals: $c a$. 33.7 Ma) is perhaps related to the persistence of regional flexural subsidence accommodating locally the effect of global sea-level drop. In other words, during the EOT and the earliest Oligocene, Shapaja biotic community turnovers have probably been primarily globally-driven, particularly for their terrestrial components (plants and mammals).

TAR-01 probably records new stable environmental conditions, under a drier and more seasonally-contrasted climate, but its highly-distinctive metatherian and rodent assemblages prevent from discussing further their sustainability at any spatiotemporal scale (Assemblage 3; Fig. 6).

\section{Conclusion}



The Shapaja section ranges the late Eocene-early Oligocene interval (ca. 36-32.5 Ma). As suggested by chemostratigraphical results, this section records both the EOT and positive carbon isotopic incursions interpreted as Oi-1 and Oi1a events. The latest Eocene-earliest Oligocene interval evidences a marine/brackish influence, as indicated by the co-occurrence of several selachians, likely forced by regional flexural subsidence. Obligate freshwater depositional environments of the uppermost part of the section are compatible with the earliest Oligocene global sea level drop. Leaf physiognomy (mainly nanophyll leaflets of compound leaves or microphyll leaves with entire margins) tentatively suggests a warm seasonal climate during the EOT interval, while the seeds of vine/epiphytic plants during the latest Eocene suggests the presence of high-canopy trees near the vicinity of streams and/or ponds. Two biotic turnovers are retrieved (metatherians, rodents, and fish): one during the late Eocene (ca. 35-36 Ma) and another one several thousand years after the EOT (ca. $33 \mathrm{Ma}$ ). TAR-21 (latest Eocene) records the first South American primates unquestionably predating the EOT. More broadly, this section documents the earliest occurrences of several genera, families, and/or superfamilies: Eopululo and Erethizontoidea (late Eocene); Paratrygon, Proargyrolagus and Argyrolagidae, Palaeothentidae, Parastegosimpsonia, Chinchilloidea, Eoincamys, and Loricariidae (latest Eocene); Adelphomyinae, Mylodontidae, Abderitidae, and true piranhas (earliest Oligocene).

The paleocommunities from Shapaja exemplify a local response of terrestrial and aquatic organisms to drastic regionally- then globally-driven changes over the late Eocene-early Oligocene interval, at low latitudes in South America.

1019

1020

1021

\section{Declaration of competing interest}

All authors declare that they do not have any conflict of interest.

1023

1024

Acknowledgments: We are indebted to Adriana Albino (Museo de La Plata, Argentina) for her taxonomic assignment of squamate remains. Fieldwork and post-field analyses in Peru were carried out thanks to the support from the National Geographic Society (grant $n^{\circ}$ 9679-15) and the Campus France program of the French Ministry of Foreign Affairs to POA, from the Doctoral School SIBAGHE/Gaia of the Montpellier University to MB, the Oak Spring Garden Foundation to F. Herrera and from the Institut des Sciences de l'Evolution de Montpellier, and The Leakey Foundation to LM. This work was further supported by an "Investissements d'Avenir" grant managed by the Agence Nationale de la Recherche (CEBA, ANR-10-LABX-25-01) and by the cooperative programs ECOS-FonCyT (A14-U01) and CoopIntEER CNRS-CONICET ( $n^{\circ} 252540$ ), in the frame of the ongoing cooperation agreement between the Museo de Historia Natural de la Universidad Nacional Mayor San Marcos (Lima, Peru) and the Institut des Sciences de l'EvolutionUniversité de Montpellier. We are particularly indebted to the invited editor, Carina Hoorn, to Robin M. D. Beck and to an anonymous reviewer for their useful comments and helpful suggestions on a previous version of the manuscript. This is the article ISEM-2021-039 SUD.

1037

1038

1039

\section{References}

Abello, M. A., 2007. Sistemática y bioestratigrafía de los Paucituberculata (Mammalia: Marsupialia) del Cenozoico de América del Sur (Doctoral dissertation, Universidad Nacional de La Plata).

Abello, M.A., Candela, A.M. 2020. Paleobiology of Argyrolagus (Marsupialia, Argyrolagidae): an astonishing case of bipedalism among South American mammals. J. Mammal. Evol. 27, 419-444.

Abello, M.A., Toledo, N., Ortiz-Jaureguizar, O., 2018. Evolution of South American Paucituberculata (Metatheria: Marsupialia): adaptive radiation and climate changes at the Eocene-Oligocene boundary, Hist. Biol., doi: $10.1080 / 08912963.2018 .1502286$ 
Adnet, S., Salas Gismondi, R., Antoine, P.-O., 2014. Comparisons of dental morphology in river stingrays (Chondrichthyes: Potamotrygonidae) with new fossils from the middle Eocene of Peruvian Amazonia rekindle debate on their evolution. Naturwissenschaften 101 (1), 33-45.

Aguilera, O.A., Bocquentin, J., Lundberg, J.G., Maciente, A., 2008. A new cajaro catfish (Siluriformes: Pimelodidae: Phractocephalus) from the Late Miocene of southwestern Amazonia and its relationship to +Phractocephalus nassi of the Urumaco Formation. Paläont Z, 82 (2), 231-245.

Anthony, H.E., Richards, J.G., 1924. A new fossil perissodactyl from Peru. Am. Mus. Novitates 111.

Antoine, P.-O. et al., 2016. A 60-million-year Cenozoic history of western Amazonian ecosystems in Contamana, eastern Peru. Gondwana Res. 31, 30-59.

Arnal, M., Kramarz, A.G., Vucetich, M.G., Frailey, C.D., Campbell, K.E., 2020. New Palaeogene caviomorphs (Rodentia, Hystricognathi) from Santa Rosa, Peru: systematics, biochronology, biogeography and early evolutionary trends. Pap. Palaeontol. 6 (2), 193-216.

Assemat, A. et al., 2019. Restes inédits de rongeurs caviomorphes du Paléogène de la région de Juanjui (Amazonie péruvienne) : systématique, implications macro-évolutives et biostratigraphiques. Geodiversitas 41 (20), 699-730.

Beard, K.C., Coster, M.C., Salem, M.J., Chaimanee, Y., Jaeger, J.-J., 2017. Biogeographic provincialism shown by AfroArabian mammals during the middle Cenozoic: climate change, Red Sea rifting and global eustasy. In: Agius, D.A., Khalil, E., Scerri, E.M.L., Williams, A. (Eds.), Human Interaction with the Environment in the Red Sea - Selected Papers of Red Sea Project VI. Koninklijke Brill NV, Leiden, pp. 48-68.

Beck, R.M.D. 2018. The Skull of Epidolops ameghinoi from the Early Eocene Itaboraí Fauna, Southeastern Brazil, and the Affinities of the Extinct Marsupialiform Order Polydolopimorphia. J. Mammal. Evol. 24, 373-414.

Benammi, M. et al., 2019. Geology, biostratigraphy and carbon isotope chemostratigraphy of the Paleogene fossilbearing Dakhla sections, Southwestern Moroccan Sahara. Geol. Mag. 156 (1), 117-132.

Berggren, W.A., Prothero, D.R. (Eds.), 1992. Eocene-Oligocene climatic and biotic evolution: an overview. Princeton University Press, Princeton, 568 pp.

Boivin, M., Marivaux, L., Antoine, P.-O., 2019a. L'apport du registre paléogène d'Amazonie sur la diversification initiale des Caviomorpha (Hystricognathi, Rodentia) : implications phylogénétiques, macroévolutives et paléobiogéographiques. Geodiversitas 41 (4), 143-245.

Boivin, M. et al., 2017. Late Oligocene caviomorph rodents from Contamana, Peruvian Amazonia. Pap. Palaeontol. 3 (1), 69-109.

Boivin, M. et al., 2018. Early Oligocene caviomorph rodents from Shapaja, Peruvian Amazonia. Palaeontographica Abt. A 311 (1-6), 87-156.

Boivin, M., Marivaux, L., Salas-Gismondi, R., Vieytes, E.C., Antoine, P.-O., 2019b. Incisor enamel microstructure of Paleogene caviomorph rodents from Contamana and Shapaja (Peruvian Amazonia). J. Mammal. Evol. 26 (3), 389-406.

Bond, M. et al., 2015. Eocene primates of South America and the African origins of New World monkeys. Nature 520, $538-541$.

Brito, P.M., Deynat, P.P., 2004. Freshwater stingrays from the Miocene of South America with comments on the rise of potamotrygonids (Batoidea, Myliobatiformes). In Arratia, G., M.V H. Wilson \& R. Cloutier, Recent advances in the origin and early radiation of vertebrates. Dr. Friedrich Pfeil, Munich, pp. 575-582.

Calvillo-Canadell, L., Cevallos-Ferriz, S.R.S., 2005. Diverse assemblage of Eocene and Oligocene Leguminosae from Mexico. Int. J. Plant Sci. 166, 671-692.

Chabain, J. et al., 2017. Cenozoic batoids from Contamana (Peruvian Amazonia) with special focus on freshwater potamotrygonins (Chondrichthyes, Myliobatiformes) and their paleoenvironmental significance. Geobios 50, 389-400.

Chornogubsky, L., Goin, F.J., 2015. A review of the molar morphology and phylogenetic affinities of Sillustania quechuense (Metatheria, Polydolopimorphia, Sillustaniidae), from the early Paleogene of Laguna Umayo, southeastern Peru. J. Vertebr. Paleontol. 35(6), e983238.

Ciancio, M.R., Carlini, A.A., Campbell, K.E., Scillato-Yané, G.J., 2013. New Palaeogene cingulates (Mammalia, Xenarthra) from Santa Rosa, Perú and their importance in the context of South American faunas. J. Syst. Palaeont. 11(6), 727-741.

Cifelli, R., Soria, M.F., 1983. Systematics of the Adianthidae (Litopterna, Mammalia). Am. Mus. Novitates, 2771, 1-25.

Coxall, H.K., Wilson, P., Palike, H., Lear, C., Backman, J., 2005. Rapid stepwise onset of Antarctic glaciation and deeper calcite compensation in the Pacific Ocean. Nature 433, 53-57.

Coxall, H.K., Pearson, P.N., 2007. The Eocene-Oligocene Transition. In: Williams, M., Haywood, A.M., Gregory, F.J., Schmidt, D.N. (Eds.), Deep-Time Perspectives on Climate Change: Marrying the Signal from Computer Models and Biological Proxies. The Micropalaeont. Soc., Spec. Pub. The Geol. Soc., London, pp. 351-387.

DeConto, R.M., Pollard, D., 2003. Rapid Cenozoic glaciation of Antarctica induced by declining atmospheric CO2. Nature 421, 245-249. 
Dunn, R.E., Strömberg, C.A.E., Madden, R.H., Kohn, M.J., Carlini, A.A., 2015. Linked canopy, climate, and faunal change in the Cenozoic of Patagonia. Science 347 (6219), 258-261.

Dupont-Nivet, G. et al., 2007. Tibetean plateau aridification linked to global cooling at the Eocene-Oligocene transition. Nature 445, 635-638.

Eldrett, J. S., Greenwood, D. R., Harding, I. C., Huber, M., 2009. Increased seasonality through the Eocene to Oligocene transition in northern high latitudes. Nature 459 (7249), 969-973.

Erhardt, A. M, Pälike, H., Paytan, A., 2013. High-resolution record of export production in the eastern equatorial Pacific across the Eocene-Oligocene transition and relationships to global climatic records. Paleoceanography 28, 130142.

Eude, A., Roddaz, M., Brichau, S., Brusset, S., Calderon, Y., Baby, P., Soula, J.-C., 2015. Controls on timing of exhumation and deformation in the northern Peruvian eastern Andean wedge as inferred from low-temperature thermochronology and balanced cross section. Tectonics 34 (4), 715-730.

Feussom-Tcheumeleu et al., 2019. Upper Miocene depositional environments and landscapes, Shumanza section, Subandean Zone, Northern Peru. Palaeobiodiversity and Palaeoenvironments 100 (3), 719-735.

Flynn, J.J., Wyss, A.R., Croft, D.A., Charrier, R., 2003. The Tinguiririca Fauna, Chile: biochronology, paleoecology, biogeography, and a new earliest Oligocene South American Land Mammal "Age". Pal. Pal. Pal. 195, 229-259.

Frailey, C.D., Campbell, K.E., 2004. Paleogene rodents from Amazonian Peru: the Santa Rosa local fauna. In: Campbell, K.E. (Ed.), The Paleogene Mammalian Fauna of Santa Rosa, Amazonian Peru. Nat. Hist. Mus. Los Angeles County, Los Angeles, pp. 71-130.

Gelfo, J.N., Alonso, R.N., Madden, R.H., Carlini, A.A., 2019. An Eocene bunodont South American native ungulate (Didolodontidae) from the Lumbrera Formation, Salta Province, Argentina. Ameghiniana 57 (2), 132-145.

Godfrey, L.R. et al., 2020. Mid-Cenozoic climate change, extinction, and faunal turnover in Madagascar, and their bearing on the evolution of lemurs. BMC Evol. Biol. 20, 97 (1-18).

Goin, F.J., Candela, A.M., 2004. New Paleogene marsupials from the Amazon Basin of eastern Peru. In: Campbell, K.E. (Ed.), The Paleogene Mammalian Fauna of Santa Rosa, Amazonian Peru. Nat. Hist. Mus. Los Angeles County, Los Angeles, pp. 15-60.

Goin, F.J., Abello, M.A., Chornogubsky, L., 2010. Middle Tertiary marsupials from central Patagonia (early Oligocene of Gran Barranca): understanding South America's Grande Coupure. In: Madden, R.H., Carlini, A.A., Vucetich, M.G., Kay, R.F. (Eds.), The Paleontology of Gran Barranca. Evolution and Environmental Change through the Middle Cenozoic of Patagonia. Cambridge Univ. Press, Cambridge, pp. 69-105.

Goin, F.J., Candela, A.M., Abello, M.A., Oliveira, E.V., 2009. Earliest South American paucituberculatans and their significance in the understanding of 'pseudodiprotodont' marsupial radiations. Zool. J. Linnean Soc. 155, 867-884.

Goin F.J., Woodburne, M.O., Zimicz, A.N., Martin, G.M., Chornogubsky, L., 2016. A brief history of South American metatherians. Springer Earth System Sciences, New York, 237 pp.

Gröcke, D.R., Hesselbo, S., Jenkyns, H.C., 1999. Carbon-isotope composition of Lower Cretaceous fossil wood: ocean atmosphere chemistry and relation to sea-level change. Geology, 27, 155-158.

Hermoza, W. et al., 2005. The Huallaga foreland basin evolution: thrust propagation in a deltaic environment, northern Peruvian Andes. J. South Am. Earth Sc. 19, 21-34.

Hoorn, C. et al., 2010. Amazonia through time: Andean uplift, climate change, landscape evolution, and biodiversity. Science 330, 927-931.

Hutchinson, D.K. et al., 2018. The Eocene-Oligocene transition: a review of marine and terrestrial proxy data, models and model-data comparisons. Climate of the Past, doi.org/10.5194/cp-2020-68.

Janis, C.M., 1993. Tertiary mammal evolution in the context of changing climates, vegetation, and tectonic events. Annu. Rev. Ecol. Syst. 24, 467-500.

Jaramillo, C., Rueda, M.J., Mora, G., 2006. Cenozoic plant diversity in the Neotropics. Science 311, 1893-1896.

Katz, M.E. et al., 2008. Stepwise transition from the Eocene greenhouse to the Oligocene icehouse. Nature Geosci. 1, 329-334.

Kay, R.F. et al., 2019. Parvimico materdei gen. et sp. nov.: a new platyrrhine from the Early Miocene of the Amazon Basin, Peru. J. Hum. Evol. 134, 102628.

Klaus, S., Magalhães, C., Salas-Gismondi, R., Gross, M., Antoine, P.-O., 2017. Palaeogene and Neogene brachyurans of the Amazon Basin: a revised first appearance date for primary freshwater crabs (Brachyura, Trichodactylidae). Crustaceana 90 (7-10), 953-967.

Koenigswald, W.v., 1997. Brief survey of the enamel diversity at the schmelzmuster level in Cenozoic placental mammals. In: Koenigswald, W.v. \& Sander, P.M. (Eds.), Tooth enamel microstructure. Rotterdam: Balkema, pp. 137-161.

Koenigswald, W.v., Martin, T., Billet, G., 2015. Enamel microstructure and mastication in Pyrotherium romeroi (Pyrotheria, Mammalia). Paläontol. Z., 89(3), 593-609. 
Kohn, M.J. et al., 2015. Quasi-static Eocene-Oligocene climate in Patagonia promotes slow faunal evolution and midCenozoic global cooling. Pal. Pal. Pal. 435, 24-37.

Lear, C.H., Bailey, T.R., Pearson, P.N., Coxall, H.K., Rosenthal, Y., 2008. Cooling and ice growth across the EoceneOligocene transition. Geology 36, 251-254.

Liu, Z. et al., 2009. Global cooling during the Eocene-Oligocene climate transition. Science 323, 1187-1190.

Luciani, V. et al., 2010. Ecological and evolutionary response of Tethyan planktonic foraminifera to the middle Eocene climatic optimum (MECO) from the Alano section (NE Italy), Pal. Pal. Pal. 292, 82- 95.

Lundberg, J.G., 1997. Fishes of the La Venta fauna: additional taxa, biotic and paleoenvironmental implications. In: Kay, R.F., Madden, R.H., Cifelli, R.L. \& Flynn, J.J. (Eds), Vertebrate paleontology in the Neotropics: The Miocene fauna of La Venta, Colombia. Smithsonian Institution Press, Washington, DC, pp. 67-91.

Lundberg, J.G., Aguilera, O., 2003. The late Miocene Phractocephalus catfish (Siluriformes: Pimelodidae) from Urumaco, Venezuela: additional specimens and reinterpretation as a distinct species. Neotrop. Ichthyol. 1(2), 97-109.

Magioncalda, R., Dupuis, C., Smith, T., Steurbaut, E. and Gingerich, P. D., 2004. Paleocene-Eocene carbon isotope excursion in organic carbon and pedogenic carbonate: Direct comparison in a continental stratigraphic section. Geology 32(7), 553-556.

Marivaux, L. et al., 2016. Neotropics provide insights into the emergence of New World monkeys: new dental evidence from the late Oligocene of Peruvian Amazonia. J. Hum. Evol. 97, 159-175.

Marivaux, L., Adnet, S., Benammi, M., Tabuce, R., Benammi, M., 2017. Anomaluroid rodents from the earliest Oligocene of Dakhla, Morocco, reveal the long-lived and morphologically conservative pattern of the Anomaluridae and Nonanomaluridae during the Tertiary in Africa. J. Syst. Palaeontol. 15 (7), 539-569.

Marivaux, L. et al., 2017. Earliest Oligocene hystricognathous rodents from the Atlantic margin of Northwestern Saharan Africa (Dakhla, Morocco): systematic, paleobiogeographical and paleoenvironmental implications. J. Vertebr. Paleontol. 37 (4), 1357567.

Marivaux, L. et al., 2005. Anthropoid primates from the Oligocene of Pakistan (Bugti Hills): data on early anthropoid evolution and biogeography. Proc. Natl. Acad. Sci. USA 102 (24), 8436-8441.

Marivaux, L., Welcomme, J.-L., Ducrocq, S., Jaeger, J.-J., 2002. Oligocene sivaladapid primate from the Bugti Hills (Balochistan, Pakistan) bridges the gap between Eocene and Miocene adapiform communities in southern Asia. J. Hum. Evol. 42 (4), 379-388.

Martínez, C. et al., submitted. Paleoclimatic and paleoecological reconstruction of a late Eocene South American tropical dry forest. Global and Planetary Change (this issue).

McKenna, M.C., Wyss, A.R., Flynn, J.J., 2006. Paleogene pseudoglyptodont xenarthrans from central Chile and Argentine Patagonia. Am. Mus. Novitates 3536, 1-18.

Meng, J., McKenna, M.C., 1998. Faunal turnovers of Palaeogene mammals from the Mongolian Plateau. Nature 394, 364-367.

Mianzan, H. et al., 2001. The Río de la Plata Estuary, Argentina-Uruguay. In: Seeliger, U., Kjerfve, B. (Eds.), Coastal Marine Ecosystems of Latin America. Springer, Berlin, Heidelberg, pp. 185-204.

Miller, K.G. et al., 2020. Cenozoic sea-level and cryospheric evolution from deep-sea geochemical and continental margin records. Science Advances 6, eaaz1346.

Miller, K.G., Wright, J., Fairbanks, R., 1991. Unlocking the icehouse: Oligocene-Miocene oxygen isotopes, eustasy and margin erosion. J. Geophys. Res. 96, 6829-6848.

Moreno, F. et al., 2020. Coupled Andean growth and foreland basin evolution, Campanian-Cenozoic Bagua Basin, northern Peru. Tectonics 39 (7), e2019TC005967.

Mudelsee, M., Bickert, T., Lear, C.H., Lohmann, G., 2014. Cenozoic climate changes: A review based on time series analysis of marine benthic $\delta 180$ records. Rev. Geophys. 52 (3), 333-374.

$\mathrm{Ni}$, X., Li, Q., Li, L., Beard, K.C., 2016. Oligocene primates from China reveal divergence between African and Asian primate evolution. Science 352 (6286), 673-677.

Noiret, C. et al., 2016. New bio-chemostratigraphic dating of a unique early Eocene sequence from southern Europe results in precise mammalian biochronological tie-points. Newslett. Strat. 49 (3), 469-480.

Pagani, M., Zachos, J.C., Freeman, K.H., Tipple, B., Bohaty, S., 2005. Marked decline in atmospheric carbon dioxide concentrations during the Paleogene. Science 309, 600-603.

Patterson, B., Roper, S.H., Richards, J.G., 1942. Two Tertiary mammals from northern South America. Am. Mus. Novitates 1173, 1-7.

Peppe, D.J., Hickey, L.J., Miller, I.M., Green, W.A., 2008. A Morphotype Catalogue, Floristic Analysis and Stratigraphic Description of the Aspen Shale Flora (Cretaceous-Albian) of Southwestern Wyoming. Bull. Peabody Mus. Nat. Hist., 49, 181-208.

Peppe, D.J., Royer, D.L., Cariglino, B., Oliver, S.Y., Newman, S., Leight, E., Enikolopov, G., Fernandez-Burgos, M., Herrera, F., Adams, J.M., Correa, E., Currano, E.D., Erickson, J.M., Hinojosa, L.F., Hoganson, J.W., Iglesias, A., 
Jaramillo, C., Johnson, K.R., Jordan, G.J., Kraft, N.L.B., Lovelock, E.C., Lusk, C.H., Niinemets, U., Penuelas, J., Rapson, G., Wing, S.L., Wright, I.J., 2011. Sensitivity of leaf size and shape to climate: global patterns and paleoclimatic applications. New Phytol. 190, 724-739.

Pérez, M.E. et al., 2019. New caviomorph rodents from the late Oligocene of Salla, Bolivia: taxonomic, chronological, and biogeographic implications for the Deseadan faunas of South America. J. Syst. Palaeont. 17 (10), 821-847.

Pol, D., Powell, J.E., 2011. A new sebecid mesoeucrocodylian from the Rio Loro Formation (Palaeocene) of northwestern Argentina. Zool. J. Linn. Soc. 163, 7-36.

Pound, M.J., Salzmann, U., 2017. Heterogeneity in global vegetation and terrestrial climate change during the late Eocene to early Oligocene transition. Sci. Rep. 7:43386, 1-12.

Premoli-Silva, I., Jenkins, D. G., 1993. Decision on the Eocene-Oligocene boundary stratotype. Episodes, 16 (3), 379-382.

Pujos, F., De Iuliis, G., Cartelle, C., 2017. A paleogeographic overview of tropical fossil sloths: towards an understanding of the origin of extant suspensory sloths?. J. Mammal. Evol. 24 (1), 19-38.

Ribeiro, A.M., López, G.M., Bond, M., 2010. The Leontiniidae (Mammalia, Notoungulata) from the Sarmiento Formation at Gran Barranca, Chubut Province, Argentina. In: Madden, R.H., Carlini, A.A., Vucetich, M.G., Kay, R.F. (Eds.), The paleontology of Gran Barranca: evolution and environmental change through the Middle Cenozoic of Patagonia Cambridge University Press, New York, pp. 170-181.

Rincón, A.D., Shockey, B.J., Anaya, F., Solórzano, A., 2015. Palaeothentid marsupials of the Salla Beds of Bolivia (late Oligocene): two new species and insights into the post-Eocene radiation of palaeothentoids. J. Mammal. Evol. 22 (4), 455-471.

Roddaz, M. et al., 2010. Cenozoic sedimentary evolution of the Amazonian foreland basin system. In: Hoorn, C., Wesselingh, F.P. (Eds.), Amazonia, Landscape and Species Evolution: A Look into the Past. Blackwell-Wiley, Hoboken, pp. 61-88.

Salas-Gismondi, R. et al., 2015. A Miocene hyperdiverse crocodylian community reveals peculiar trophic dynamics in proto-Amazonian mega-wetlands. Proc. Roy. Soc. B 282, 20142490.

Sánchez Fernández, A.W., Chira Fernández, J.E., Valencia Muñoz, M.M., 1997. Geología de los cuadrángulos de Tarapoto, Papa Playa, Utcurarca y Yanayacu 13-k, 13-I, 14-k, 14-I. INGEMMET Boletín A, 94, Lima, 237 pp.

Sánchez-Villagra, M.R., Kay, R. F., 1997. A skull of Proargyrolagus, the oldest argyrolagid (Late Oligocene Salla Beds, Bolivia), with brief comments concerning its paleobiology. J. Vertebr. Paleontol., 17(4), 717-724.

Sánchez-Villagra, M.R. 2001. The phylogenetic relationships of argyrolagid marsupials. Zool. J. Linnean Soc. 131(4), 481-496.

Sarkar, A., Sarangib, S., Ebiharac, M., Bhattacharyad, S.K., Raye, A.K., 2003. Carbonate geochemistry across the Eocene/Oligocene boundary of Kutch, western India: implications to oceanic O2-poor condition and foraminiferal extinction. Chem. Geol. 201 (3-4), 281-293.

Savage, D.E., Russell, D.E., 1983. Mammalian Paleofaunas of the World. Addison-Wesley, Reading, MA, $432 \mathrm{pp}$.

Sedor, F. A., Oliveira, É.V., Silva, D.D., Fernandes, L.A., Cunha, R.F., Ribeiro, A.M., \& Dias, E.V., 2017. A new South American Paleogene land mammal fauna, Guabirotuba Formation (southern Brazil). J. Mammal. Evol. 24 (1), 39-55.

Seiffert, E.R., 2007. Evolution and extinction of Afro-Arabian Primates near the Eocene-Oligocene boundary. Folia Primatol. 78, 314-327.

Seiffert, E.R. et al., 2020. A parapithecid stem anthropoid of African origin in the Paleogene of South America. Science 368, 194-197.

Shellis, R.P., Berkovitz, B.K.B., 1976. Observations on the dental anatomy of piranhas (Characidae) with special reference to tooth structure. J. Zoology 180 (1), 69-84.

Shockey, B.J., Anaya, F., 2011. Grazing in a new late Oligocene mylodontid sloth and a mylodontid radiation as a component of the Eocene-Oligocene faunal turnover and the early spread of grasslands/savannas in South America. J. Mammal. Evol. 18 (2), 101-115.

Shockey, B.J., Flynn, J.J., Croft, D.A., Gans, P., Wyss, A.R., 2012. New leontiniid Notoungulata (Mammalia) from Chile and Argentina: comparative anatomy, character analysis, and phylogenetic hypotheses. Am. Mus. Novitates 3737, $1-64$.

Simpson, G.G., 1967. The beginning of the Age of Mammals in South America. Bull. Am. Mus. Nat. Hist. 137, 1-259.

Soria, M.F., Hoffstetter, R., 1983. Présence d'un Condylarthre (Salladolodus deuterotherioides gen. et sp. nov.) dans le Déséadien (Oligocène inférieur) de Salla, Bolivie. CR Acad. Sci. 2, 297 (6), 549-552.

Stehlin, H.G., 1909. Remarques sur les faunules de mammifères des couches éocènes et oligocènes du Basin de Paris. Bull. Soc. Geol. France 9 (4), 488-520.

Storme, J.-Y. et al., 2012. Paleocene/Eocene boundary section at Zumaia (Basque-Catabric Basin) revisited: new insights from high resolution magnetic susceptibility and carbon isotope chemostratigraphy on organic matter $\left(\delta^{13} C_{\text {org }}\right)$ : Terra Nova $24,310-317$. 
Toledo, C.E.V., Bertini, R.J., 2005). Occurrences of the fossil dipnoiformes in Brazil and its stratigraphic and chronological distributions. Rev. Brasil. Paleontol. 8 (1), 47-57

Toumoulin, A. et al., 2020. Quantifying the effect of the Drake Passage opening on the Eocene Ocean. Pal. Pal. Pal. 35, e2020PA003889.

Tramoy, R. et al., 2016. Stepwise paleoclimate change across the Eocene-Oligocene transition recorded in continental NW Europe by mineralogical assemblages and $\delta^{15} \mathrm{~N}_{\text {org }}$ (Rennes Basin, France). Terra Nova 28, 212-220.

Traverse, A., 2007. Paleopalynology: Second Edition, 2nd ed, Topics in Geobiology. Springer Netherlands.

Vandenberghe, N., Hilgen, F.J., Speijer, R.P., 2012. Chapter 28: The Paleogene period. In: Gradstein, F.M., Ogg, J.G., Schmitz, M., Ogg, G. (Eds.), The Geological Time Scale 2012. Elsevier Science Ltd, Oxford, pp. 855-921.

Van Mourik, C., Brinkhuis, H., 2005. The Massignano Eocene-Oligocene golden spike section revisited. Stratigraphy 2 (1), 13-30.

Villarroel, C., 2000. Un nuevo Mylodontinae (Xenarthra, Tardigrada) en la fauna de La Venta, Mioceno de Colombia: el estado actual de la familia Orophodontidae. Rev. Acad. Colomb. Cie. Ex., Físicas y Naturales 24 (90), $117-128$.

Wade, B. S., Pälike, H., 2004. Oligocene climate dynamics. Paleoceanography 19 (4), PA4019.

Westerhold, T. et al., 2020. An astronomically dated record of Earth's climate and its predictability over the last 66 million years. Science $369,1383-1387$.

Woodcock, D.W., Meyer, H.W., Prado, Y., 2017. The Piedra Chamana fossil woods (Eocene, Peru). IAWA Journal 38, 313-365.

Wolff, R.G., 1984. A new early Oligocene argyrolagid (Mammalia: Marsupialia) from Salla, Bolivia. J. Vertebr. Paleontol. 4 (1), 108-113.

Yans, J. et al., 2010. Carbon-isotope of fossil wood and dispersed organic matter from the terrestrial Wealden facies of Hautrage (Mons basin, Belgium). Pal., Pal., Pal. 291, 85-105.

Yans, J. et al., 2014a. First carbon chemostratigraphy of the Ouled Abdoun phosphate Basin, Morocco: implications for dating and evolution of earliest African placental mammals. Gondw. Res. 25, 257-269.

Yans, J. et al., 2014b. Refined bio- (benthic foraminifera, dinoflagellate cysts) and chemostratigraphy $\left(\delta^{13} \mathrm{C}_{\mathrm{org}}\right)$ of the earliest Eocene at Albas-Le Clot (Corbières, France): implications for mammalian biochronology in Western Europe. Newslett. Stratigr. 47(3), 331-353.

Yeo, D.C., Ng, P.K., Cumberlidge, N., Magalhaes, C., Daniels, S.R., Campos, M.R., 2007. Global diversity of crabs (Crustacea: Decapoda: Brachyura) in freshwater. In: Balian, E.V., Lévêque, C., Segers, H., Martens, K. (Eds.), Freshwater animal diversity assessment. Springer, Dordrecht, pp. 275-286.

Zachos, J.C., Dickens, G.R., Zeebe, R.E., 2008. An early Cenozoic perspective on greenhouse warming and carbon-cycle dynamics. Nature 451, 279-283.

Zachos, J.C., Pagani, M., Sloan, L., Thomas, E., Billups, K., 2001. Trends, rhythms, and aberrations in global climate 65 Ma to Present. Science 292, 686-693.

Zanazzi, A., Kohn, M.J., MacFadden, B.J., Terry, D.O., 2007. Large temperature drop across the Eocene-Oligocene transition in Central North America. Nature 445, 639-642.

Zhifei, L., Shouting, T., Quanhong Z., Xinrong, C., Wei, H., 2004. Deep-water Earliest Oligocene Glacial Maximum (EOGM) in South Atlantic: Chin. Sci. Bull., 49 (20), 2190-2197. 